Supporting Information for

\title{
Navigating multidimensional social-ecological system tradeoffs across sanitation alternatives in an urban informal settlement
}

John T. Trimmer, Hannah A.C. Lohman, Diana M. Byrne, Stephanie A. Houser, Fulgensio Jjuuko, David Katende, Noble Banadda, Assata Zerai, Daniel C. Miller, Jeremy S. Guest

\section{Table of Contents (29 total pages):}

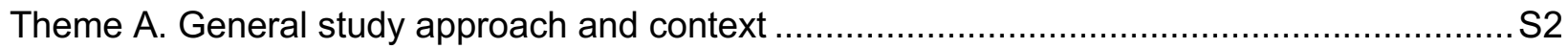

Figure S1. Sanitation social-ecological systems framework variables in this study.............S2

Figure S2. Map of the study site within its broader national context................................... S3

Figure S3. Photographs of Bwaise and the Lubigi Treatment Plant ................................... S4

Theme B. Quantitative modeling around sanitation alternatives in Bwaise, Uganda ................ S5

Section S1. General approach to quantitative scenario modeling ...................................S5

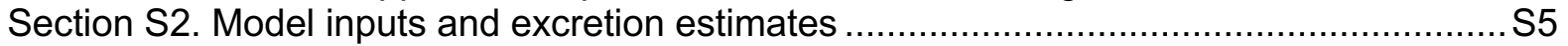

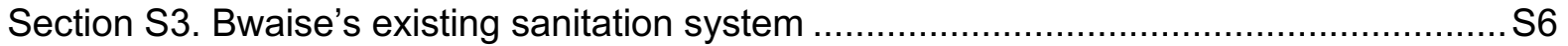

Section S4. CIDl's proposed treatment center................................................................ 10

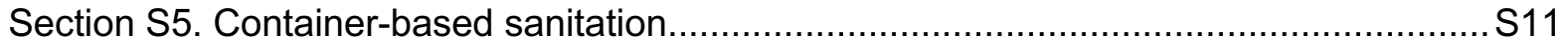

Section S6. Additional sensitivity analyses ................................................................... 12

Figure S4. Overview of model structure .................................................................. 14

Figure S5. Sensitivity of model outputs to key parameters across all scenarios ...............S15

Table S1. Summary of alternative sanitation scenarios .............................................. 16

Table S2. Parameters used as initial inputs common to all scenarios .............................S17

Table S3. Parameters used in the User interface process stage ................................... S18

Table S4. Parameters used in the Decentralized storage process stage .......................... S19

Table S5. Parameters used in the Conveyance process stage ..................................... S20

Table S6. Parameters used in the Centralized treatment process stage..........................S21

Table S7. Parameters used in the Reuse/disposal process stage ..................................S23

Theme C. Household surveys in Bwaise, Uganda ..................................................... S24

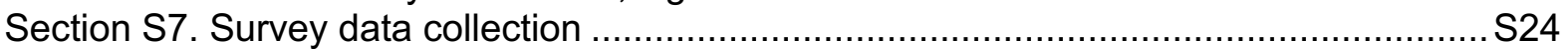

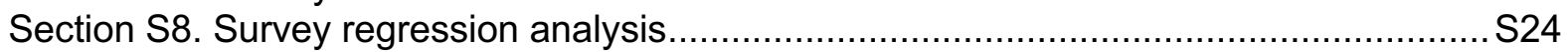

Figure S6. Sensitivity analysis on regression model odds ratios ................................ S26

Table S8. Screening results for variable inclusion in survey regression analysis ..............S27

Table S9. Relationships identified from Chi-square standardized residuals analysis.........S28

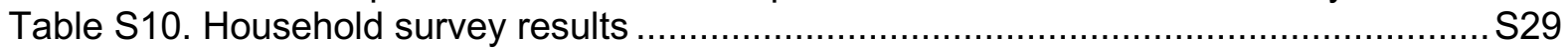

Table S11. Sample questions from household survey instrument................................ 30

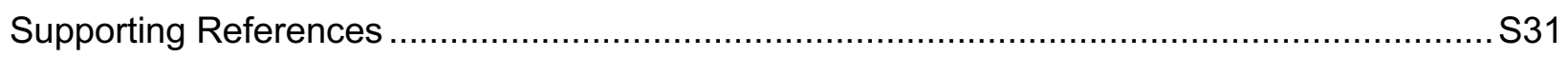


Theme A. General study approach and context

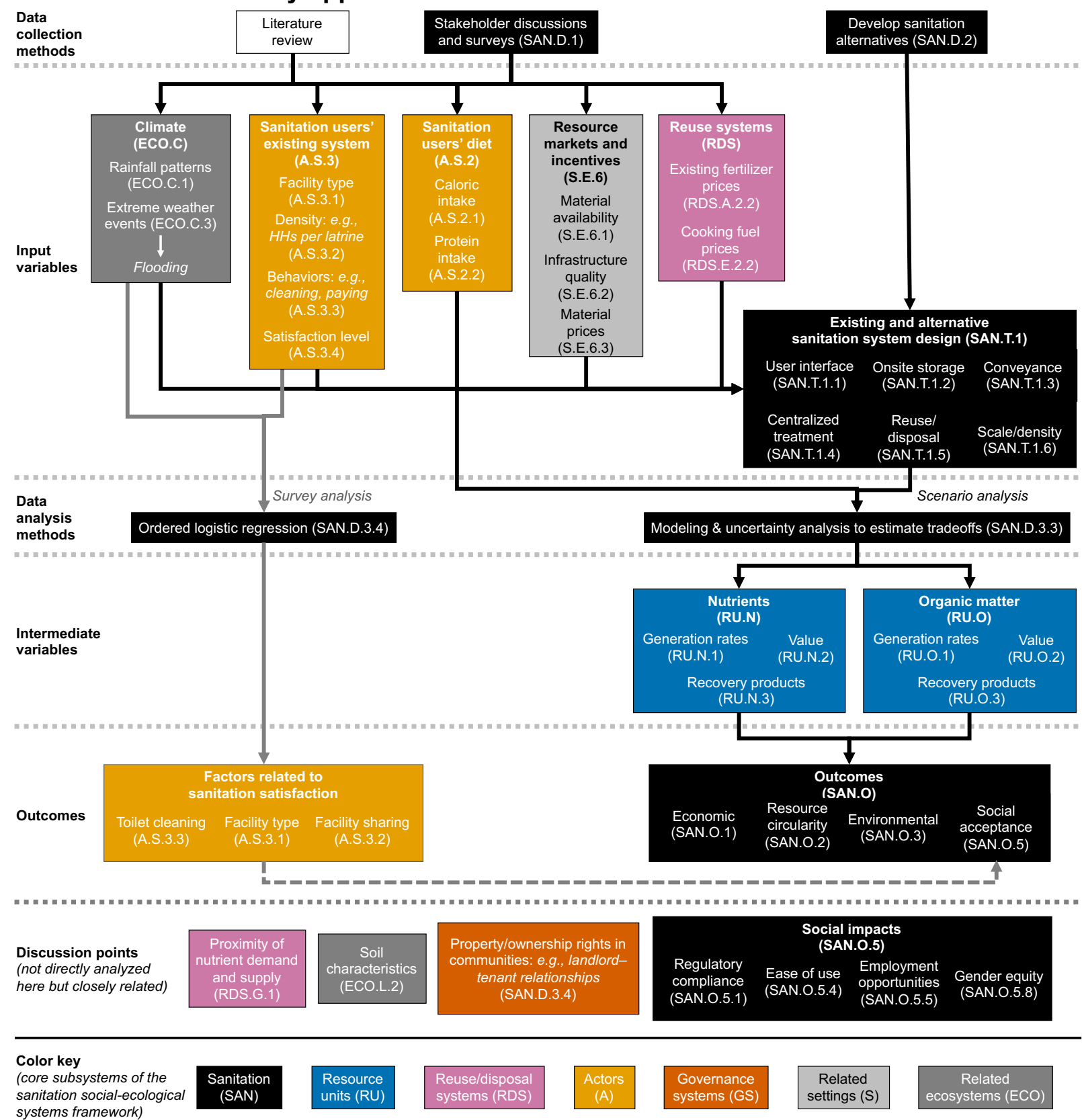

Figure S1. Examples of variables from the sanitation social-ecological systems (S-SES) framework $^{1}$ included in this study's analysis of sanitation alternatives in Bwaise, Uganda. The variables pictured here do not represent an exhaustive list of all parameters included in our analysis, but rather exemplify the different types of information that were considered. As shown by their vertical position, some variables informed the methods used, some acted as inputs, intermediates, or outputs of those methods, and still others factored into the study as discussion points. Note that gray arrows reflect variables associated with survey analysis (shown on the left), while scenario modeling is shown on the right. Variables are color-coded according to the subsystem of the S-SES framework that contains them (see the color key at the bottom). In many cases, multiple third- or fourth-tier variables nested within a single, higher-level variable are included, and these are typically displayed together within a single box. More detail on this nested, multi-tiered structure can be found in the parallel study that describes the framework in full. ${ }^{1}$ 
(a) Uganda

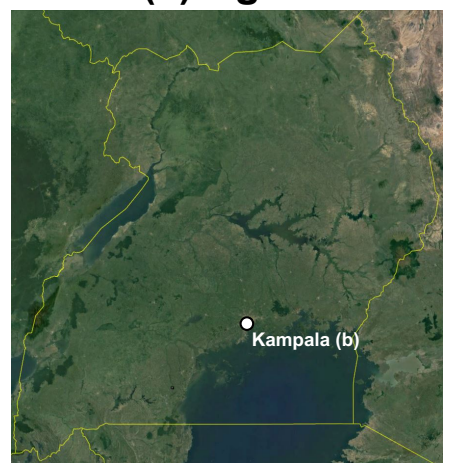

(b) Kampala

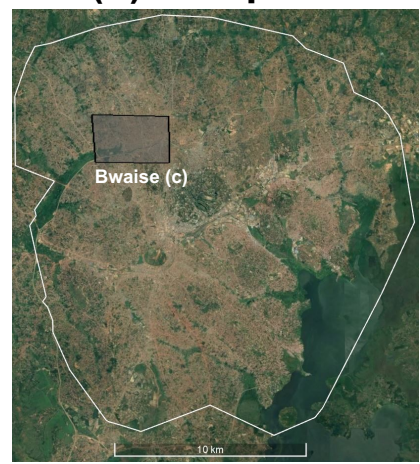

(c) Bwaise

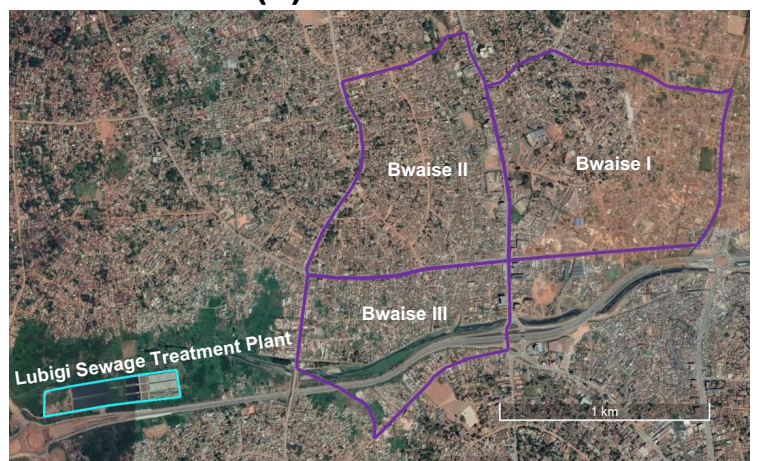

Figure S2. Map of the study site within its broader national context, showing Kampala's location in Uganda (a), Bwaise's location in Kampala (b), and the three parishes of Bwaise (c). Bwaise I, II, and III are outlined in purple, and the Lubigi Sewage Treatment Plant is outlined in light blue. Each parish contains ten zones (i.e., villages), and three representative zones were selected from each parish in collaboration with community leaders from all zones to ensure adequate geographic representation across Bwaise. Aerial images were taken from Google Earth. 


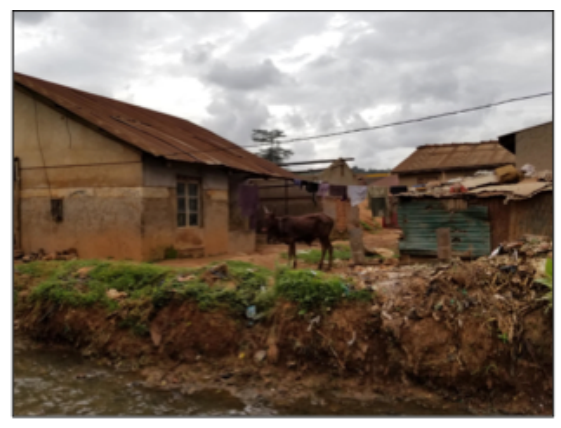

(a) Bwaise dwellings and a local drainage channel

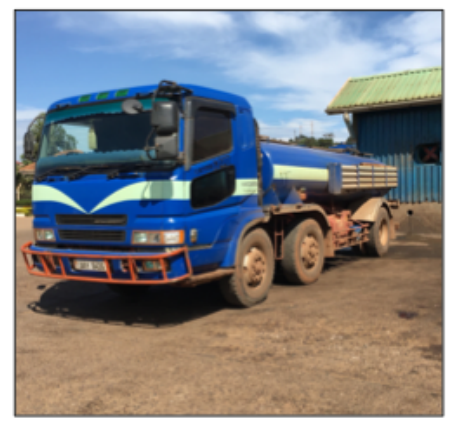

(d) Tanker truck at Lubigi Treatment Plant

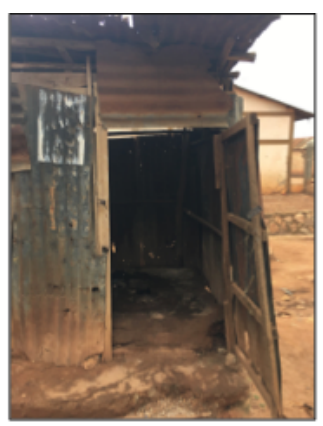

(b) Pit latrine in Bwaise

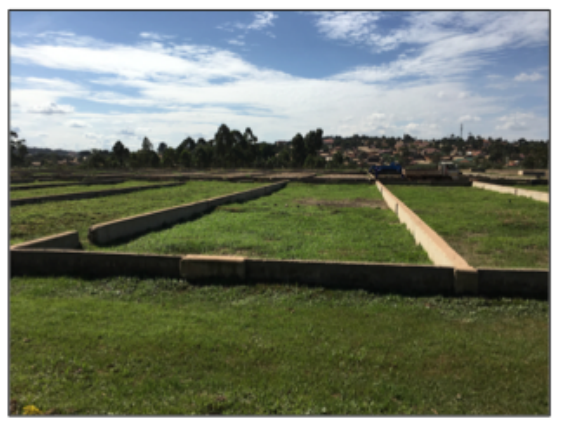

(e) Solids drying beds at Lubigi Treatment Plant

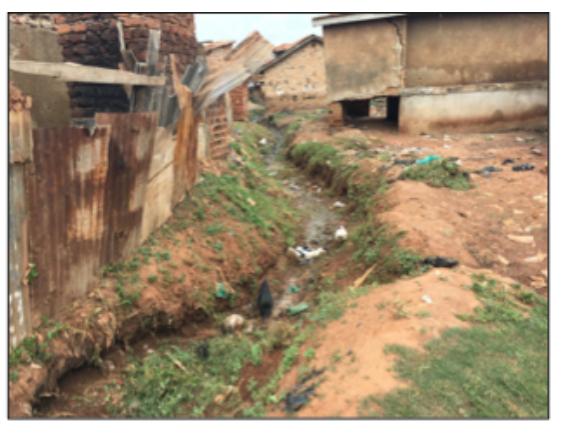

(c) Drainage channel in Bwaise

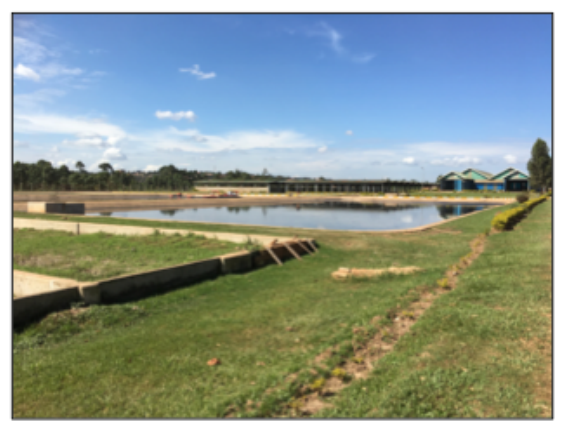

(f) Wastewater lagoon at Lubigi Treatment Plant

Figure S3. Photographs of Bwaise informal settlement and the Lubigi Sewage Treatment Plant. 


\section{Theme B. Quantitative modeling around sanitation alternatives in Bwaise, Uganda}

Section S1. General approach to quantitative scenario modeling. Details regarding the methodology and assumptions used to quantitatively model the resource recovery potential, net life cycle costs, and net greenhouse gas (GHG) emissions associated with each of the three sanitation system alternatives for Bwaise, Uganda are provided in the following sections. A number of tables (Tables S2-S7) present values, uncertainty ranges and distributions, and literature references for all parameters used in these analyses. To account for uncertainty and assess sensitivity of outcomes (e.g., costs, emissions, recovery potentials) to various input parameters, we employed a Monte Carlo analysis with Latin Hypercube Sampling (10,000 simulations). For each uncertain input parameter (Tables S2-S7), we calculated Spearman's rank correlation coefficients ${ }^{2}$ to assess the sensitivity of each modeled outcome to that parameter. We also conducted additional sensitivity analyses to evaluate the individual impacts of a few specific changes to key parameters or conditions (see Section S6 for details).

Generally, the model was implemented within a modular structure that separated each sanitation system alternative into distinct process stages related to the user interface, onsite storage, conveyance, centralized treatment and resource recovery, and reuse or disposal. ${ }^{3,4}$ Each process stage could include separate modules for liquids and solids (if source separation is practiced onsite, or if separation processes occur during centralized treatment) or modules for combined excreta. Additionally, process stages focused on centralized treatment/resource recovery and reuse/disposal accommodated the possibility of multiple modules representing multi-stage treatment approaches (e.g., the existing system includes sedimentation followed by lagoons for liquid treatment and drying beds for solids management). Each module contained various processes (e.g., organic degradation, methane emission, cost calculations for pit emptying) resulting in transformations, losses, costs, and emissions. The outputs of each module defined the remaining resources $(\mathrm{N}, \mathrm{P}, \mathrm{K}, \mathrm{COD}$, water) and total mass of material, as well as cumulative costs and emissions. The outputs of one module formed the inputs of the next, until, at the end of the process sequence, an output spreadsheet was generated to summarize the results (for the system as a whole, as well as for each process stage). The model code was developed in Python (version 3.6) ${ }^{5}$ and implemented using Spyder (version 3.2.3). ${ }^{6}$ All model parameters were defined in an associated spreadsheet and are automatically imported whenever the model is run (allowing parameter to be updated easily). The code is openly available on GitHub. ${ }^{7}$

Section S2. Model inputs and excretion estimates. Initial inputs common to all alternative systems included parameters regarding dietary intake, bodily waste excretion, and general assumptions related to biological degradation, the economic environment, and GHG emissions potential (Table S2). The resource content of urine and feces (i.e., excretion rates of nitrogen, phosphorus, potassium, and chemical oxygen demand [COD]) was estimated from dietary intake following procedures used in previous work. ${ }^{8,9}$ To summarize, per capita caloric and protein supply data for Uganda in 2013 were extracted from the UN Food and Agricultural Organization's statistical database (FAOSTAT). ${ }^{10}$ These data account for supply chain losses and wastes up to the household level. As household food waste is typically low in sub-Saharan Africa, ${ }^{11}$ we assumed household losses were negligible. To account for variations in diet across households and individuals, we defined an uncertainty range by increasing and decreasing the reported values by $10 \%$. From protein and caloric intake, we then estimated nutrient intake. Nitrogen was computed as a fraction of total protein supply (13-19\%), ${ }^{12,13}$ while phosphorus was calculated using two separate fractions, depending on whether the protein is plant- or animal-based. ${ }^{9,12}$ We estimated potassium using a factor converting from caloric intake to potassium. ${ }^{14,15} \mathrm{Next}$, a fraction of intake is excreted. We assumed nitrogen and phosphorus excretion is at or near $100 \%$ of intake. ${ }^{16,17}$ A lower excretion factor was used for potassium, because some ingested potassium 
$(2-35 \%)$ leaves the body in sweat. ${ }^{14,15}$ Finally, to estimate COD excretion, an excretion factor (2$10 \%)^{18-20}$ was applied to caloric intake to estimate per capita energy excretion, and this energy value was converted to COD by calculating a conservative lower heating value of excreta $(14 \mathrm{~kJ} \cdot \mathrm{g}$ $\mathrm{COD}^{-1}$, assuming the organic matter in excreta contains $50 \%$ protein, $40 \%$ carbohydrates, and $10 \%$ fats). ${ }^{21}$ This process of estimating per capita resource excretion is represented by the equations below (Eqs. 1-4):

$$
\begin{gathered}
N_{\text {cap }}=\left(p_{\text {tot }}\right)\left(N_{\text {prot }}\right)\left(N_{\text {exc }}\right) \\
P_{\text {cap }}=\left[\left(P_{\text {prot }, v}\right) p_{\text {veg }}+\left(P_{\text {prot }, a}\right) p_{\text {anim }}\right]\left(P_{\text {exc }}\right) \\
K_{\text {cap }}=\left(e_{\text {cal }}\right)\left(K_{\text {cal }}\right)\left(K_{\text {exc }}\right) \\
C O D_{\text {cap }}=\left(e_{\text {cal }}\right)\left(e_{\text {exc }}\right)\left(L H V_{W W}\right)^{-1}
\end{gathered}
$$

where $N_{\text {cap }}, P_{\text {cap }}, K_{\text {cap }}$, and $C O D_{\text {cap }}$ represent per capita excretion of nitrogen, phosphorus, potassium, and COD (kg N $\left.\cdot \mathrm{cap}^{-1} \cdot \mathrm{yr}^{-1}, \mathrm{~kg} \mathrm{P} \cdot \mathrm{cap}^{-1} \cdot \mathrm{yr}^{-1}, \mathrm{~kg} \mathrm{~K} \cdot \mathrm{cap}^{-1} \cdot \mathrm{yr}^{-1}, \mathrm{~kg} \mathrm{COD} \cdot \mathrm{cap}^{-1} \cdot \mathrm{yr}^{-1}\right) ; p_{\text {tot }}$

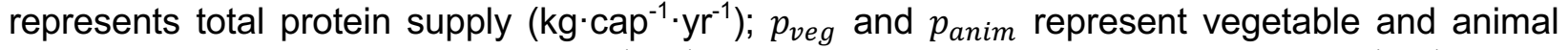

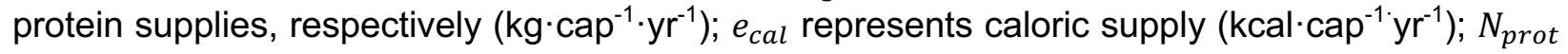
represents the fraction of nitrogen contained in total protein; $P_{\text {prot }, v}$ and $P_{\text {prot, } a}$ represent the fractions of phosphorus contained in vegetable and animal protein, respectively; $K_{\text {cal }}$ represents

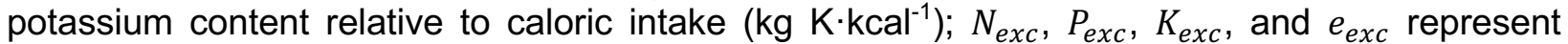
nitrogen, phosphorus, potassium, and energy excretion factors (total excreted in urine and feces as a fraction of intake); and $L H V_{W W}$ represents wastewater's lower heating value (kJ.g COD ${ }^{-1}$, which can be converted to $\mathrm{kcal} \cdot \mathrm{kg} \mathrm{COD}^{-1}$ by multiplying by a unit conversion factor of 239 ).

These equations estimate total resource excretion in urine and feces. We used relevant literature ${ }^{18,22}$ to identify typical fractions of each resource excreted in each waste stream (e.g., the percentage of total excreted nitrogen found in urine). From the literature, we also defined total excretion rates of urine and feces, the typical moisture content of each stream, and typical calcium and magnesium excretion rates in each stream. ${ }^{18,22}$ The fraction of excreted nitrogen present in a reduced and inorganic form (urea or ammonia) ${ }^{18,22,23}$ was also important to consider, as ammonia volatilization may cause substantial nitrogen losses during various processes.

Additional parameters related to economics (local currency exchange rate, discount/interest rate), ${ }^{24}$ GHG emissions (e.g., equivalent 100-year $\mathrm{CO}_{2}$ emissions associated with methane and nitrous oxide), ${ }^{25}$ and the rate of biological degradation during storage were also included in this set of initial inputs. We assumed that degradation and transformation processes (e.g., breakdown of easily biodegradable COD, nitrification and denitrification) followed first-order reaction kinetics $\left(\mathrm{C}=\mathrm{C}_{\mathrm{o}} \mathrm{e}^{-\mathrm{kt}}\right)$, with "full" degradation occurring after 1-3 years (full degradation was represented as 2-4 log reduction, as first-order exponential decay does not allow for complete $100 \%$ degradation). From these assumptions, a first-order degradation rate constant can be calculated.

Section S3. Bwaise's existing sanitation system. The existing sanitation system in Bwaise, Uganda includes pit latrines (typically shared by multiple households), ${ }^{26,27}$ conveyance of latrine contents via tanker trucks, and centralized treatment at the Lubigi Sewage Treatment Plant (which involves sedimentation, lagoons for liquid treatment, and drying beds for solids management). Within the first process stage, the user interface combines all materials entering the latrine pit, 
including urine, feces, anal cleansing material (assumed to be toilet paper), ${ }^{28,29}$ and flushing or cleaning water. ${ }^{30,31}$ While toilet paper or other added materials may contribute non-negligible quantities of resources such as COD to the pit contents, we only tracked nutrients and COD contributed by urine and feces, to prevent our results from becoming dependent upon cleansing material or flush water composition. However, we did track the mass of each added material, which may increase transport requirements. Additionally, several parameters related to the materials, costs, and GHG emissions associated with latrine construction and operation were considered here (Table S3). Construction and operating costs were based on the results of a separate study performed in the same context. ${ }^{32}$ For this and subsequent process stages, an inventory of items generating GHG emissions was acquired using the ecoinvent v3.2 database ${ }^{33}$ accessed within SimaPro v8.5.2.0, a software for implementing life cycle assessment. Emissions were converted to equivalent kilograms of $\mathrm{CO}_{2}$ using the U.S. EPA's Tool for the Reduction and Assessment of Chemicals and Other Environmental Impacts (TRACl; 2.1 v1.03, implemented within SimaPro v8.5.2.0). ${ }^{34}$ Within this process stage, we also estimated the number of users per latrine, based on our survey results related to household size (median of 4 people per household, with a standard deviation of 1.8) and latrine sharing (3-5 households per toilet). All model outcomes (resource recovery potential, costs, GHG emissions) for each scenario were normalized to report annual per capita results, using the number of users and an assumed latrine lifetime (5-10 years). ${ }^{32,35}$ Construction costs and other non-annual costs were annualized using the facility lifetime and an assumed annual discount rate (3-6\%). ${ }^{24,36}$

In the onsite storage process stage, mixed excreta accumulate in the latrine pit and remain there until emptying. A great deal of uncertainty surrounds the processes occurring in this stage (e.g., water and nutrient infiltration into surrounding soil, ammonia volatilization, methane and $\mathrm{CO}_{2}$ emissions from anaerobic and/or aerobic COD degradation, biological nitrogen transformation and $\mathrm{N}_{2} \mathrm{O}$ emission from incomplete denitrification). We reviewed relevant literature to characterize the accumulation, losses, and emissions resulting from many of these processes, although reported estimates are often highly variable (Table S4; e.g., nitrogen losses of $1-50 \%$ through leaching; sludge accumulation rates of $\left.100-900 \mathrm{~L} \cdot \mathrm{cap}^{-1} \cdot \mathrm{yr}^{-1}\right) .{ }^{23,26,31,37-40} \mathrm{We}$ also assumed $60-80 \%$ of COD was easily biodegradable (and would fully degrade due to biological activity if given sufficient time), while $70-90 \%$ of nitrogen was readily available for nitrification and denitrification processes. ${ }^{23}$ For simplicity, we assumed all latrine pits were unlined and above the groundwater table, with approximately $50 \%$ of COD degradation occurring anaerobically and $\leq 0.1 \%$ of transformed nitrogen being emitted as nitrous oxide. ${ }^{41}$ To account for the non-steady state nature of pit latrine operation, we made several additional simplifying assumptions. First, we assumed that each new excreta deposit forms a layer that does not mix with previous deposits, and we assumed infiltration and volatilization processes occurred relatively quickly, happening before degradation and transformation processes (assumed to occur less rapidly). In each layer, easily biodegradable COD and readily available nitrogen degrade according to first-order reaction kinetics (assumptions used to estimate the rate constant are described in Section S2). When the waste is collected and removed from the latrine, all layers are removed together, with each layer at a different point along the first-order decay curve. We assumed the COD and nitrogen concentrations in the evacuated waste can be represented as the average of the concentrations across all layers, calculated using the mean value theorem for integrals (i.e., integrating the firstorder decay function from the start to the emptying time, and dividing by the elapsed time; Eq. 5).

$$
C_{a v g}=\frac{C_{o}}{k\left(t_{f}-t_{o}\right)}\left(e^{-k t_{o}}-e^{-k t_{f}}\right)
$$

where $C_{\text {avg }}$ represents the average concentration when the latrine is emptied; $C_{o}$ represents the initial concentration; $k$ is the first-order rate constant; and $t_{o}$ and $t_{f}$ represent the starting time 
and ending time, respectively. The differences between the initial concentrations and the averages calculated after storage were then used with the IPCC methodology ${ }^{41}$ to calculate methane and $\mathrm{N}_{2} \mathrm{O}$ emissions during the storage period. According to the IPCC methodology for methane, a given quantity of degraded COD is associated with a maximum potential methane production $\left(0.25 \mathrm{~kg} \mathrm{CH}_{4} \cdot \mathrm{kg} \mathrm{COD}^{-1}\right) .{ }^{41}$ Based on environmental conditions, an appropriate methane correction factor (MCF) is then applied to estimate actual methane emissions. For example, a MCF of 0.25 signifies conditions where $25 \%$ of COD degradation occurs anaerobically. For $\mathrm{N}_{2} \mathrm{O}$, the emission factor (e.g., $0.1 \%$ ) is multiplied by total transformed nitrogen to estimate how much nitrogen leaves the system as $\mathrm{N}_{2} \mathrm{O}$.

The conveyance process stage involves pumping out the contents of full pit latrines into tanker trucks, which then transport the collected sludge to centralized treatment. Of the quantities of nutrients and COD remaining in the sludge after onsite storage, we assumed small fractions $(\leq 5 \%)$ would be lost during pumping and transport. Based on our discussions with local stakeholders and literature on local latrine emptying costs associated with different volumes and various conditions (e.g., consistency of sludge, presence of other materials in the pit that must be removed first), ${ }^{42,43}$ we developed power law regressions to estimate the emptying fee associated with a given sludge volume. These relationships resulted in emptying costs of 18,000-38,000 Ugandan shillings (US \$5-10) per cubic meter of sludge removed, with this fee covering all costs incurred by truck drivers (e.g., fuel, maintenance, personal protective equipment, discharge fees at the treatment plant, taxes). We assumed transport distances of 2-10 kilometers (based on a Google Maps distance of 4-5 kilometers from central locations in Bwaise to the Lubigi Sewage Treatment Plant, with added uncertainty), and the emissions factor associated with transport (kilograms of equivalent $\mathrm{CO}_{2}$ per tonne-kilometer) was based on factors reported for a variety of truck types and sizes. ${ }^{33,34}$ The mass to be transported reflected the sludge accumulation rate during onsite storage, with the emptying period (i.e., the time between emptying events) was assumed to be roughly equivalent to latrine filling times (calculated from sludge accumulation rates and pit volumes estimated from survey results and relevant literature). ${ }^{26,27}$

The centralized treatment process stage is modeled after the Lubigi Sludge Treatment Plant, which includes sedimentation basins to separate solids and liquids, followed by unplanted drying beds for solids management and a series of lagoons (anaerobic and facultative) for liquid treatment. For the most part, the physical design (e.g., volumes, dimensions) of these treatment components was established based on discussions with Lubigi operators, process flow diagrams they provided, and direct visual assessment. Any performance data that could not be provided by the Lubigi operators was estimated from relevant literature (Table S6). Latrine sludge discharged from trucks enters one of two 1,250- $\mathrm{m}^{3}$ sedimentation basins. These basins are used in an alternating fashion, with operation switching every 1-2 months to allow for removal of accumulated solids. We assumed a final solids content of settled sludge of $10-20 \%$, with total solids and COD retention of $35-60 \%$. We assumed the fractions of nutrients retained in settled sludge were roughly equivalent to the fractions of total excreted nutrients present in feces. ${ }^{22}$ Any COD degradation occurring in the settled sludge before it is removed from the basin was assumed to be predominantly (80-100\%) anaerobic, and $\mathrm{N}_{2} \mathrm{O}$ emissions were expected to be negligible, as nitrification requires oxygen as the electron acceptor. ${ }^{44}$ After removal from the sedimentation basin, settled sludge is stored in covered and uncovered drying beds for a period of at least 6 months, where sludge may reach a final solids content of $30-40 \%$. Lubigi houses a total of 19 sludge storage beds (deeper than drying beds to provide additional storage capacity), 19 covered drying beds, and 30 uncovered drying beds. We assumed drying beds provide a relatively aerobic environment $(0-30 \%$ of $\mathrm{COD}$ degrading anaerobically $),{ }^{41}$ which also suggests that nitrification/denitrification processes may be more substantial here $(\leq 1.1 \%$ available nitrogen emitted as $\mathrm{N}_{2} \mathrm{O}$ ). ${ }^{45}$ Liquids leaving the sedimentation basin enter three $4,640-\mathrm{m}^{3}$ anaerobic 
lagoons operated in parallel, which may remove $60-70 \%$ of influent COD. ${ }^{46}$ We assumed this removed COD settles, and the easily biodegradable fraction degrades over time in the lagoon's anaerobic environment. Following the anaerobic lagoons are two $11,530-\mathrm{m}^{3}$ facultative lagoons, also operated in parallel. COD removal efficiencies of $70-90 \%$ are expected, ${ }^{46}$ with removed COD degrading over time in a predominantly aerobic environment. Overall, Lubigi operators report that the total installation cost of the plant was approximately USD 18.6 million. It is expected to operate for 8-11 years and currently serves 30,000 sewered customers (below its planned design population of 50,000 ). Additionally, the plant manages approximately $500 \mathrm{~m}^{3} \cdot \mathrm{d}^{-1}$ of fecal sludge collected from latrines. Only fecal sludge enters the sedimentation basin, while the lagoons treat wastewater as well as the liquid effluent from sedimentation. Based on CIDI's expectations regarding the alternative plant's daily sludge flow rate and population served, we estimated the total population of latrine users served by the existing plant. To estimate GHG emissions from construction, we approximated the quantities of key materials (e.g., concrete, metal roofing, structural steel, plastic lagoon liners, excavation) that would have been necessary to build these treatment processes and obtained relevant emissions impact factors. ${ }^{33,34}$ Limitations on data availability prevented a complete life cycle assessment that incorporated all construction materials, but our results (using the key materials listed above, which likely represent the majority of construction emissions) showed that GHG emissions from treatment plant construction are relatively minor when compared with other emissions categories (e.g., direct emissions from excreta degradation, latrine construction). Lubigi operators report the plant requires $4,760 \mathrm{kWh}$ of electricity per month, and we assume that electricity is the main contributor to operational GHG emissions. We applied a unit GHG impact factor of $0.106-0.121 \mathrm{~kg} \mathrm{CO}_{2} \mathrm{eq} \cdot \mathrm{kWh}^{-1}$ to estimate emissions from electricity. This GHG factor is based on Uganda's electricity mix, which is dominated by hydroelectric power. ${ }^{33,47}$ Major operational costs include electricity and salaries for twelve employees. The unit cost of electricity was based on various categories of local tariffs (USD 0.08-0.21· $\mathrm{kWh}^{-1}$ ).

In the reuse or disposal process stage, we assumed that farmers purchase all dried solids, and that all treated liquid effluent is used to irrigate cropland. In reality, the plant discharges liquid effluent into local wetlands, but some crop production occurs in this ecosystem. To estimate the maximum benefits from resource recovery in this existing scenario, we assume both liquids and solids are purchased by farmers for cropland application. The transfer process (e.g., farmers load dried solids onto trucks for transport to farms) is assumed to result in some small resource losses (Table S7), ${ }^{48}$ and we assume the purchase price depends upon nutrient content. We collected prices of several single-nutrient fertilizers (e.g., urea, triple superphosphate, potassium chloride) in Kampala and also used available data on national retail prices in Uganda from 2010 to 2017 to estimate a price per kilogram of each nutrient (nitrogen, phosphorus, and potassium). ${ }^{49}$ We then used our median estimates of the nutrient content in dried solids to compute the price per tonne of solids, if a kilogram of each nutrient in dried solids is given the same value as a kilogram of that nutrient in retail fertilizers. Finally, we compared this price estimate with the range of solids selling prices currently reported by the Lubigi plant (18,000-60,000 Ugandan shillings per tonne of dried sludge, or approximately US $\$ 5-17 \cdot$ tonne $^{-1}$ ). Through this comparison, we calculated a discount factor, representing the inconveniences and reductions in perceived value associated with using dried sludge rather than retail fertilizers (e.g., dried sludge is bulkier, requires more energy for transport, and may contain more variable quantities of nutrients). By multiplying the estimated nutrient concentrations in dried sludge by their fertilizer unit prices (per kilogram of nutrient) and this discount factor, we estimated the value of sludge produced at the treatment plant. Due to a lack of data on the value of organic matter independent of nutrients, we note that this procedure does not account for the organic content of the sludge, which may also offer agricultural benefits when land applied. Also due to a lack of relevant data, we assumed that nutrients recovered in liquid effluent can be valued similarly to those in dried sludge, with the same discount factor. This 
calculated value from recovered solids and liquids represents an economic benefit from resource recovery and reuse, and it functions to reduce the overall net costs associated with this sanitation alternative. Analogously, land application of these resources can offset GHG emissions that would have resulted from the production of fertilizers (if we assume sludge application replaces existing or potential future fertilizer use). We identified $\mathrm{GHG}$ impact factors (equivalent $\mathrm{CO}_{2}$ emissions per kilogram of nitrogen, phosphorus, or potassium produced) associated with the production of several single-nutrient fertilizers (e.g., urea, ammonium nitrate, single superphosphate, triple superphosphate, potassium chloride) ${ }^{33,34}$, using these to estimate offsets associated with the nutrients embedded in dried sludge and liquid effluent. These offsets functioned to lessen the overall net GHG emissions of the sanitation system.

Section S4. CIDI's proposed anaerobic treatment center. The second sanitation alternative employs the same onsite latrines and truck conveyance processes as the existing system. Therefore, the assumptions and procedures relevant for the user interface, onsite storage, and conveyance process stages do not change. The difference comes in the centralized treatment processes that occur. The proposed treatment center includes anaerobic digestion of mixed waste in a three-chambered anaerobic baffled reactor (including a filter at the end), followed by unplanted and planted drying beds for solids management and a planted bed for secondary treatment of liquids. We designed all components using relevant literature and information from CIDI (Table S6). The anaerobic baffled reactor (with filter) was designed with an overall hydraulic retention time of $1-5$ days $^{21,50}$ and is expected to remove $83-99 \%$ of influent COD and $0-15 \%$ of total nitrogen. ${ }^{21,50}$ As with the existing treatment system, we approximated the quantities of key materials needed to build these alternative treatment facilities (e.g., concrete, steel, filter media), combining these quantities with impact factors to estimate GHG emissions associated with construction. Regarding operation, we estimated electricity use based on Lubigi's consumption, scaled according to the plant's daily sludge capacity (as CIDI does not yet have precise estimates of operational needs). Construction costs were based on estimates performed by CIDI engineers, and operating expenses (including labor and electricity) were calculated based on electricity consumption and staffing expectations. The overall system has a treatment capacity of $60 \mathrm{~m}^{3}$ of sludge per day, which is considerably lower than the capacity of the existing Lubigi plant. The expected lifetime of the system is reported to be approximately 50 years, substantially longer than the existing plant's expected lifetime. Normalizing all outcomes on an annual, per capita basis allows for direct comparison between these two alternatives, although it is important to note their differences in scale.

Assumptions around the reuse of recovered materials were similar to those for the existing system, with cost and emissions offsets depending upon the nutrient content of products. With regard to methane-rich biogas recovered from anaerobic digestion, losses during operation, collection, and storage may range from negligible levels in well-designed and efficiently managed systems to $20 \%$ under less ideal circumstances. ${ }^{51}$ We assume the value will fall somewhere within this $0-20 \%$ range. As liquid petroleum gas (LPG) is likely the closest analog to biogas readily available in this context, we assume the energetic content of recovered methane will have a similar economic value to an equivalent quantity of energy provided in LPG tanks currently available for purchase. Based on price data collected from local vendors, the cost to refill an empty LPG tank (after the tank had already been purchased) is estimated to be 6,000-6,700 Ugandan shillings per kilogram (US $\$ 1.50-1.90 \cdot \mathrm{kg} \mathrm{LPG}^{-1}$ ), and the specific energy of $L P G^{52}$ is reported to be approximately $50 \mathrm{MJ} \cdot \mathrm{kg}^{-1}$. This income from the sale of biogas represents a reduction in the system's total net costs. Similarly, we assume that combustion of biogas for cooking will offset LPG combustion. While $90 \%$ of surveyed households in Bwaise reported using charcoal as their cooking fuel, we focus on a comparison between biogas and LPG because these alternatives likely provide similar levels of service and indoor air quality (both biogas and LPG are reported to 
emit less particulate matter than charcoal). ${ }^{46,53}$ Furthermore, comparing biogas with LPG (as opposed to charcoal) represents a more conservative approach to estimating GHG offsets. Especially when charcoal is burned in inefficient traditional stoves, LPG contributes smaller quantities of GHG emissions than charcoal not originating from sustainably managed forests (deforestation rates and diminishing areas of forested land in Uganda suggest forests are often not managed sustainably). ${ }^{10,54}$ We assume that LPG cooking stoves have roughly the same efficiency as biogas stoves, ${ }^{51,54}$ and that approximately three kilograms of carbon dioxide equivalents are emitted from burning one kilogram of LPG ${ }^{55}$ We calculate offsets by converting the energy recovered in biogas to an equivalent mass of LPG (in terms of energetic content) and multiplying by the emissions factor of $3 \mathrm{~kg} \mathrm{CO} \mathrm{eq} \cdot \mathrm{kg} \mathrm{LPG}^{-1}$.

Section S5. Container-based sanitation. The final system alternative replaces existing pit latrines with a container-based approach. Toilet facilities associated with container-based sanitation typically separate urine and feces, storing each material in a removable container that can be collected and replaced with an empty one. We assume the costs and greenhouse gas emissions associated with the construction of a container-based toilet facility will be similar to those of a urine-diverting dry toilet. ${ }^{32}$ We assume users add a desiccant (e.g., wood ash) to the fecal collection container after each toilet use $\left(200-500 \mathrm{~mL} \cdot \mathrm{cap}^{-1} \cdot \mathrm{d}^{-1}\right)$ to reduce moisture content and control odors. ${ }^{46}$ If left indefinitely, the moisture content is assumed to decrease slowly over time down to an absolute minimum of $7-13 \%$, according to an estimated first-order exponential decay constant $\left(0.009-0.011 \mathrm{~d}^{-1}\right) \cdot{ }^{56}$ The feces container is assumed to be mostly aerobic $(5-15 \%$ of COD degradation is anaerobic), with potential $\mathrm{N}_{2} \mathrm{O}$ emissions similar to those in pit latrines $(\leq 0.1 \% \text { of available nitrogen })^{41}$

When urine is stored, the $\mathrm{pH}$ increase driven by the hydrolysis of urea induces precipitation of minerals (primarily struvite and hydroxyapatite when collected urine is not diluted). ${ }^{57,58}$ Struvite $\left(\mathrm{MgNH}_{4} \mathrm{PO}_{4} \cdot 6 \mathrm{H}_{2} \mathrm{O}\right)$ forms from magnesium, ammonium, and phosphate ions, and is typically limited by magnesium concentrations in undiluted urine. Precipitation of hydroxyapatite $\left(\mathrm{Ca}_{5}\left(\mathrm{PO}_{4}\right)_{3} \mathrm{OH}\right)$ tends to be limited by calcium concentrations. ${ }^{57-59}$ These processes occur relatively quickly (i.e., within less than a few days), ${ }^{57,59}$ so we assume they have already reached equilibrium when containers are collected for transport to the centralized facility. Based on influent concentrations of constituent ions, we estimate the quantity of struvite precipitated at equilibrium using a conditional solubility product $\left(\mathrm{pK}_{\mathrm{sp}}{ }^{\text {cond }}=7.3-8.1\right)$ estimated for typical applications involving source-separated urine $\left(\mathrm{pH}=9\right.$, temperature $=25^{\circ} \mathrm{C}$, ionic strength $\left.=0.16-0.61\right) .{ }^{60}$ As hydroxyapatite's solubility product is reported to be quite small $\left(\mathrm{pK}_{\mathrm{sp}}=57.5\right),{ }^{57}$ we assumed that calcium ions in solution (which are typically the limiting constituent in undiluted urine) would be negligible after equilibrium has been reached. In other words, hydroxyapatite precipitation would incorporate essentially all calcium ions that are available, along with the corresponding quantity of phosphate ions (based on the mineral's molar ratio). In urine storage containers, most precipitated minerals are reported to settle and contribute to the formation of a viscous sludge, which can be recovered along with the liquid. ${ }^{48,58}$ However, we do assume that a highly uncertain fraction (0-50\%) of precipitated minerals forms a hard scale on the walls of the storage container, ${ }^{58}$ which may be more difficult to remove. To be conservative, we treat this fraction as a loss that is unavailable for recovery. We also assume that $0-7 \%$ of total nitrogen is lost through ammonia volatilization. ${ }^{23,48,61}$

Container-based systems often employ one or more manual pushcarts to collect urine and feces containers from each toilet facility and provide users with clean, empty containers. An analysis that modeled this type of collection system in similar contexts (informal settlements in Kampala, Uganda and Raipur, India) estimated costs to be US\$0.004-0.015 $\mathrm{cap}^{-1} \cdot \mathrm{d}^{-1}$ when the pushcart system operated under a performance-based payment scheme (i.e., workers are paid according 
to the number of serviced facilities) and served at least 200 users ${ }^{24}$ Costs under a fixed payment scheme, where workers receive a fixed daily payment, were similar when the system served at least 700 individuals. ${ }^{24}$ We assume pushcart collection costs will fall within a similar range in Bwaise. However, we also assume an additional transport step to convey collected containers to a centralized treatment facility such as the Lubigi plant. Pushcarts would load collected containers onto a truck parked in the settlement, and then this truck would take the containers to the treatment plant. As with the other sanitation alternatives, we assume that small losses of nutrients and COD $(\leq 5 \%)$ may occur during these conveyance processes, although losses may be less likely in this case, since the waste is confined within closed containers. Based on CIDl's local experience, trucking costs were estimated to be $\$ 4-8 \cdot \mathrm{m}^{-3}$ of collected waste. GHG emissions associated with transporting a given mass by truck were assumed to be similar to those in the preceding alternatives.

After conveyance, we assumed that centralized treatment and recovery processes are the same as those employed in the existing system alternative, enabling us to investigate the specific impact of replacing pit latrines with container-based facilities. Within the existing treatment approach, sedimentation is no longer necessary for separation of solids and liquids, because feces and urine already arrive at the treatment plant in separate containers. Accordingly, sedimentation is removed from the treatment sequence. We acknowledge that the existing treatment system (drying beds, wastewater lagoons) may not be the most appropriate approach for the desiccated feces and stored urine that will now be entering the plant. However, we continue to employ these processes because we have applicable cost data from the existing plant, and more appropriate alternatives (e.g., composting of solids, extended storage of urine) may be associated with similar infrastructure. While our goal with this scenario was to understand the specific implications of transitioning from pit latrines to container-based facilities within the existing sanitation system, future work should examine the downstream process changes that may be needed to most effectively accommodate the different inputs entering centralized treatment. Reuse assumptions surrounding crop application of dried solids and treated liquid effluent were also the same as in the existing system.

Section S6. Additional sensitivity analyses. To evaluate the individual impacts of certain specific changes to model parameters or conditions, we conducted additional sensitivity analyses related to the following topics: (i) discount rate; (ii) lifetime of the anaerobic treatment facility; (iii) latrine pits extending below the groundwater table; (iv) single-household latrines; and (v) pit latrine emptying practices. Each of these analyses is described below.

(i) Discount rate. Across all modeled scenarios, we employed a discount rate of $3-6 \%$ to annualize any non-annual costs (e.g., construction of latrines and treatment plants). ${ }^{24,36}$ We assessed the impact of increasing this discount rate to $9-10 \%$ (consistent with the rate used by Uganda's Central Bank when providing loans to commercial banks). ${ }^{62}$ In all three scenarios, this change increased the median net cost of the overall system by $11-13 \%$, but the trends across scenarios remained the same. Scenario B (8.94 USD $\left.\operatorname{cap}^{-1} \cdot \mathrm{yr}^{-1}\right)$ remained less expensive than the existing system (16.16 USD cap $\left.^{-1} \cdot \mathrm{yr}^{-1}\right)$, while Scenario $\mathrm{C}(24.62$ USD $\operatorname{cap}^{-1} \cdot \mathrm{yr}^{-1}$ ) remained more expensive.

(ii) Anaerobic treatment facility lifetime. The estimated lifetime of the anaerobic treatment facility (used in Scenario B) was 50 years, as reported by Community Integrated Development Initiatives (CIDI, our partner organization). As this lifetime may represent an optimistic estimate, we assessed the impact of decreasing it to 10 years (similar to the expected lifetime of the existing treatment plant). Even with this considerable change, however, we see only a $7 \%$ increase in Scenario B's median net cost (8.39 USD $\left.\operatorname{cap}^{-1} \cdot \mathrm{yr}^{-1}\right)$ and a 5\% increase in its median net greenhouse gas emissions $\left(28.6 \mathrm{~kg} \mathrm{CO}_{2}\right.$ eq $\left.\mathrm{cap}^{-1} \cdot \mathrm{yr}^{-1}\right)$. These results, which remain well below the costs and emissions associated with the existing 
system, confirm that the anaerobic facility's longer lifetime is not skewing the results in favor of Scenario B.

(iii) Latrine pits below the groundwater table. To represent the existing system as favorably as possible, we assumed no latrine pits extended below Bwaise's shallow groundwater table. Conditions in communal latrine pits above the water table are assumed to be approximately $50 \%$ aerobic and $50 \%$ anaerobic. ${ }^{23,41}$ In this sensitivity analysis, we assessed the impact of pits that do extend below the water table, where anaerobic conditions are more prevalent $(70-100 \%),{ }^{41}$ generating additional methane emissions. We found that direct emissions from pit latrines increased by $59 \%$, and overall net greenhouse gas emissions from the entire sanitation system increased by $30 \%$ (28-33\%).

(iv) Single-household latrines. Due to the large prevalence of shared latrines in Bwaise (as shown in our survey results), we modeled pit latrines as being shared by 3-5 households in our existing system. However, because our survey analysis showed that single-household facilities are correlated with increased user satisfaction levels, we assessed the impact of supplying every household with its own latrine. Single-household latrines are expected to have lower greenhouse gas emissions than shared facilities, due to less anaerobic conditions (5-15\%) resulting from better management. However, we found that the increased emissions associated with construction of additional latrines (to supply each household with its own facility) outweighed the reduced direct emissions from the latrine pits. Overall net emissions increased by $8-34 \%$, while total net costs more than doubled (an increase of 108-187\%) due to severely increased construction costs associated with building more latrines.

(v) Latrine emptying. To assess the full potential of the three sanitation scenarios under ideal conditions, we assumed that all toilet facilities were emptied appropriately, with excreta being transported to the treatment plant. However, numerous issues related to affordability, accessibility, and governance limit the degree to which appropriate collection and transport occurs in practice. ${ }^{43,63,64}$ We assessed the impacts on scenario outcomes if a fraction of toilets were not emptied appropriately. As an extreme case, we assumed that excreta from $41 \%$ of toilets was discharged directly to an open drain or open water body, either by the owner of the facility or an unlicensed emptier (Peal et al. estimate that $41 \%$ of onsite sanitation facilities in Kampala are not safely managed, due to inappropriate emptying and other issues). ${ }^{65}$ We used emission factors for discharge to aquatic environments to estimate greenhouse gas emissions from this unsafe emptying, ${ }^{41}$ and we assumed this emptying occurred at no cost (while this assumption is unrealistic unless toilet owners empty or discharge sludge themselves, we employed it to assess the greatest possible change in economic outcomes). This analysis increased median emissions from Scenario B by $41 \%$ (up to $38 \mathrm{~kg} \mathrm{CO} 2 \mathrm{eq} \cdot \mathrm{cap}^{-1} \cdot \mathrm{yr}^{-1}$ ) and from Scenario $\mathrm{C}$ by $73 \%$ (to $37 \mathrm{~kg} \mathrm{CO}$ eq $\cdot \mathrm{cap}^{-1} \cdot \mathrm{yr}^{-1}$ ), while the change was negligible $(<1 \%)$ for Scenario A (53 $\mathrm{kg} \mathrm{CO}_{2}$ eq $\left.\cdot \mathrm{cap}^{-1} \cdot \mathrm{yr}^{-1}\right)$. Essentially, these altered assumptions undercut some of the large environmental benefits observed for the two alternative scenarios. Resource recovery potentials in all three scenarios declined by approximately $41 \%$, because this fraction of resources did not reach the treatment plant where recovery could occur. Changes in economic outcomes (even with the extreme assumption that non-ideal emptying occurred at no cost) were relatively minor in all cases $(5-6 \%)$ and did not change overall trends across the three scenarios. 


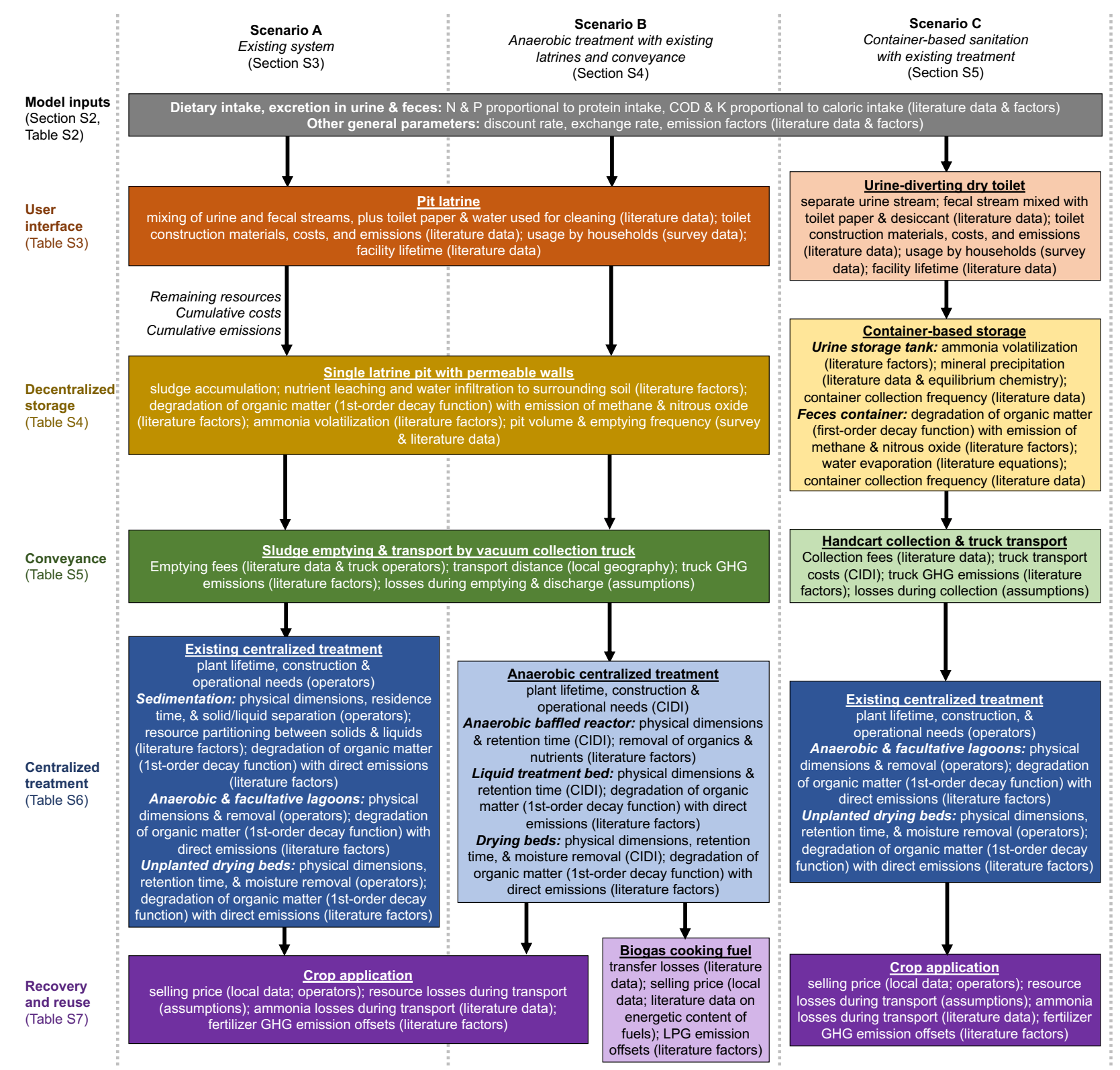

Figure S4. Overview of modeling structure in the three sanitation scenarios. Each scenario is modeled using a sequence of modules representing each stage of the sanitation chain. Boxes with lighter shading and black text indicate difference(s) from the existing system. In some cases, a stage contains multiple modules. Container-based storage incorporates the urine storage tank and feces container operating in parallel, while the centralized treatment stage in all scenarios employs multiple treatment processes acting in series. In Scenario B's reuse stage, crop application and biogas modules operate in parallel. The outputs of each module (remaining quantities of N, P, K, COD, water, and total mass; cumulative costs and emissions) act as inputs to the following module. Within each module, various processes occur (described by the text in each box), resulting in transformations, losses, costs, emissions, and offsets that affect the outputs of that module. In parentheses, we note the type(s) of sources for all data and calculations involved in each module. The three scenario models are described in greater detail in Sections S3-S5, the general model inputs are described in Section S2 and Table S2, and the parameters that define each module are shown in Tables S3-S7. The model code was developed using Python 3.6 and implemented in Spyder 3.2.3. The code is openly available on GitHub. ${ }^{7}$ 


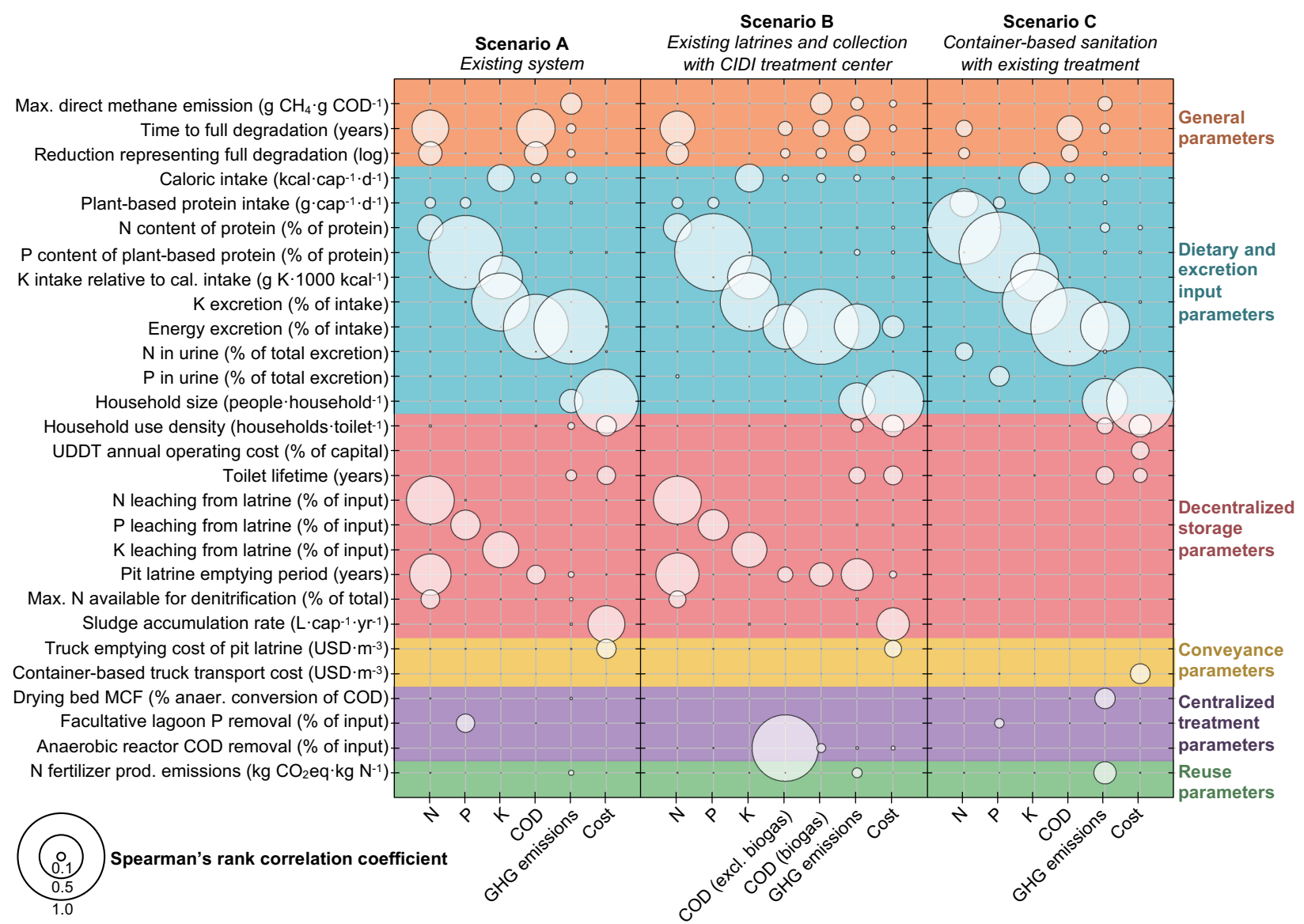

Figure S5. The relative importance of key parameters to the uncertainty associated with the outputs of each scenario (N, P, K, and COD recovery potentials; net GHG emissions; net costs). The size of each bubble is proportional to the absolute value of the Spearman's rank correlation coefficient associated with each parameter and output combination, calculated using the results from 10,000 simulations included in the uncertainty analysis. Spearman's coefficients estimate the degree to which variations in an output have a monotonic relationship with variations in an input parameter's value. Each parameter shown in this figure has a coefficient with an absolute value of at least 0.20 for at least one output in at least one scenario. Parameters are divided into categories according to their stage along the sanitation chain (background shading). 
Table S1. Summary of alternative sanitation scenarios modeled for Bwaise, Uganda. Each sanitation alternative is described as an interconnected sequence of processes. Cells with gray shading and white text indicate differences from the existing sanitation system.

\begin{tabular}{|c|c|c|c|c|c|c|}
\hline & Scenario & $\begin{array}{c}\text { User } \\
\text { interface }\end{array}$ & $\begin{array}{c}\text { Onsite } \\
\text { storage/treatment }\end{array}$ & Conveyance & $\begin{array}{c}\text { Centralized } \\
\text { treatment/recovery }\end{array}$ & Reuse or disposal \\
\hline (a) & $\begin{array}{l}\text { Existing } \\
\text { system }\end{array}$ & $\begin{array}{l}\text { Dry or } \\
\text { pour-flush } \\
\text { toilet }\end{array}$ & Single latrine pit & $\begin{array}{l}\text { Tanker truck for } \\
\text { pumping out and } \\
\text { transporting latrine } \\
\text { contents when pit is } \\
\text { full }\end{array}$ & $\begin{array}{l}\text { Sedimentation; } \\
\text { covered and uncovered } \\
\text { drying beds (solids); } \\
\text { anaerobic and facultative } \\
\text { lagoons (liquids) }\end{array}$ & $\begin{array}{l}\text { Cropland application } \\
\text { of treated solids and } \\
\text { liquids }\end{array}$ \\
\hline (b) & $\begin{array}{l}\text { CIDI } \\
\text { anaerobic } \\
\text { treatment } \\
\text { center }\end{array}$ & $\begin{array}{l}\text { Dry or } \\
\text { pour-flush } \\
\text { toilet }\end{array}$ & Single latrine pit & $\begin{array}{l}\text { Tanker truck for } \\
\text { pumping out and } \\
\text { transporting latrine } \\
\text { contents when pit is } \\
\text { full }\end{array}$ & $\begin{array}{l}\text { Anaerobic baffled reactor; } \\
\text { unplanted and planted } \\
\text { drying beds (solids); } \\
\text { planted bed (liquids) }\end{array}$ & $\begin{array}{l}\text { Cropland application } \\
\text { of treated solids and } \\
\text { liquids; } \\
\text { biogas collection for } \\
\text { cooking fuel }\end{array}$ \\
\hline (c) & $\begin{array}{l}\text { Container- } \\
\text { based } \\
\text { sanitation }\end{array}$ & $\begin{array}{l}\text { Urine- } \\
\text { diverting } \\
\text { dry toilet }\end{array}$ & $\begin{array}{l}\text { Liquid container; } \\
\text { solids container } \\
\text { (with desiccant } \\
\text { addition) }\end{array}$ & $\begin{array}{l}\text { Container collection } \\
\text { with manual push- } \\
\text { carts, transferred to } \\
\text { truck for transport to } \\
\text { treatment facility }\end{array}$ & $\begin{array}{l}\text { Covered and uncovered } \\
\text { drying beds (solids); } \\
\text { anaerobic and facultative } \\
\text { lagoons (liquids) }\end{array}$ & $\begin{array}{l}\text { Cropland application } \\
\text { of treated solids and } \\
\text { liquids }\end{array}$ \\
\hline
\end{tabular}


Table S2. Parameter values, ranges, and distributions used as initial inputs common to all scenarios in the quantitative modeling analysis.

\begin{tabular}{|c|c|c|c|c|c|}
\hline Parameter & Expected value & Low value & High value & Distribution & References \\
\hline Caloric intake $\left(\mathrm{kcal} \cdot \mathrm{cap}^{-1} \cdot \mathrm{d}^{-1}\right)$ & 2,130 & 1,917 & 2,343 & uniform & 10 \\
\hline Vegetable protein intake $\left(g \cdot \mathrm{cap}^{-1} \cdot \mathrm{d}^{-1}\right)$ & 40.29 & 36.26 & 44.32 & uniform & 10 \\
\hline Animal protein intake $\left(\mathrm{g} \cdot \mathrm{cap}^{-1} \cdot \mathrm{d}^{-1}\right)$ & 12.39 & 11.15 & 13.63 & uniform & 10 \\
\hline $\mathrm{N}$ content of protein $(\%)$ & 13 & 13 & 19 & uniform & 12,13 \\
\hline $\mathrm{P}$ content of veg. protein $(\%)$ & 2.2 & 0.4 & 4.8 & triangular & 12,66 \\
\hline $\mathrm{P}$ content of animal protein $(\%)$ & 1.1 & 0.2 & 3.2 & triangular & 12,66 \\
\hline $\mathrm{K}$ content of cal. intake $\left(\mathrm{g} \mathrm{K} \cdot 1000 \mathrm{kcal}^{-1}\right)$ & 1.2 & 1.1 & 1.5 & uniform & 14,15 \\
\hline $\mathrm{N}$ excretion (\% of intake) & 100 & 99 & 100 & uniform & 16,17 \\
\hline $\mathrm{P}$ excretion (\% of intake) & 100 & 99 & 100 & uniform & 16,17 \\
\hline K excretion (\% of intake) & 88 & 65 & 98 & uniform & 14,67 \\
\hline Energy excretion (\% of intake) & 6 & 2 & 10 & uniform & $18-20$ \\
\hline $\mathrm{N}$ in urine (\% of total) & 88 & 74 & 93 & triangular & 18,22 \\
\hline $\mathrm{P}$ in urine (\% of total) & 61 & 33 & 75 & triangular & 18,22 \\
\hline $\mathrm{K}$ in urine $(\%$ of total) & 74 & 53 & 93 & triangular & 18,22 \\
\hline Energy in feces (\% of total) & 81 & 69 & 90 & triangular & 18,22 \\
\hline Urine $\mathrm{N}$ in reduced inorganic form (\%) & 85 & 75 & 90 & uniform & 18,22 \\
\hline Feces $\mathrm{N}$ in reduced inorganic form (\%) & 20 & 16 & 24 & uniform & 18,23 \\
\hline Urine excretion $\left(\mathrm{g} \cdot \mathrm{cap}^{-1} \cdot \mathrm{d}^{-1}\right)$ & 1,400 & 800 & 2,500 & triangular & 18,22 \\
\hline Feces excretion $\left(g \cdot \operatorname{cap}^{-1} \cdot d^{-1}\right)$ & 250 & 75 & 520 & triangular & 18,22 \\
\hline Urine moisture content (\%) & 95 & 93 & 97 & triangular & 18,22 \\
\hline Feces moisture content (\%) & 85 & 76 & 88 & triangular & 18,22 \\
\hline $\mathrm{Mg}$ in urine $\left(\mathrm{g} \mathrm{Mg} \cdot \operatorname{cap}^{-1} \cdot \mathrm{d}^{-1}\right)$ & 0.2 & 0.12 & 0.21 & uniform & $22,57,59$ \\
\hline$M g$ in feces $\left(g \mathrm{Mg} \cdot \operatorname{cap}^{-1} \cdot \mathrm{d}^{-1}\right)$ & 0.25 & 0.15 & 0.34 & uniform & 22 \\
\hline 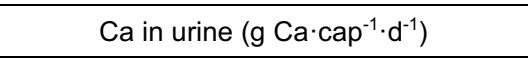 & 0.28 & 0.057 & 0.5 & uniform & 22 \\
\hline Ca in feces $\left(\mathrm{g} \mathrm{Ca} \cdot \operatorname{cap}^{-1} \cdot \mathrm{d}^{-1}\right)$ & 1.9 & 0.1 & 3.6 & uniform & 22 \\
\hline Max. methane emission $\left(\mathrm{g} \mathrm{CH}_{4} \cdot \mathrm{g} \mathrm{COD}^{-1}\right)$ & 0.25 & 0.175 & 0.325 & triangular & 44 \\
\hline Time to full degradation (years) & 2 & 1 & 3 & uniform & (assumption) \\
\hline Reduction rep. full degradation (log units) & 3 & 2 & 4 & uniform & (assumption) \\
\hline $\mathrm{N}_{2} \mathrm{O}$ GWP $\left(\mathrm{kg} \mathrm{CO}{ }_{2}\right.$ eq $\left.\cdot \mathrm{kg} \mathrm{N}_{2} \mathrm{O}^{-1}\right)$ & 265 & 265 & 298 & uniform & 25 \\
\hline $\mathrm{CH}_{4} \mathrm{GWP}\left(\mathrm{kg} \mathrm{CO} \mathrm{eq} \cdot \mathrm{kg} \mathrm{CH}_{4}^{-1}\right)$ & 28 & 28 & 34 & uniform & 25 \\
\hline Exchange rate $\left(U G X \cdot U_{S D}^{-1}\right)$ & 3,700 & 3,600 & 3,900 & triangular & Bank of Uganda, 2019 \\
\hline Annual discount rate $(\%)$ & 5 & 3 & 6 & uniform & 24 \\
\hline
\end{tabular}


Table S3. Parameter values, ranges, and distributions used in the user interface process stage of the quantitative modeling analysis. Parameters related to pit latrines are used in Scenarios A$\mathrm{B}$, while those related to urine-diverting dry toilets (UDDTs) are used in Scenario C (Table S1).

\begin{tabular}{|c|c|c|c|c|c|}
\hline Parameter & Expected & Low & High & Dist. & References \\
\hline Toilet paper addition (sheets $\cdot \operatorname{cap}^{-1} \cdot \mathrm{d}^{-1}$ ) & 12.4 & 11.7 & 14.2 & uniform & 28,29 \\
\hline Toilet paper solid mass $\left(\mathrm{mg} \cdot\right.$ sheet $\left.^{-1}\right)$ & 545 & 511 & 578 & uniform & 28,29 \\
\hline Water addition $\left(\mathrm{L} \cdot \mathrm{cap}^{-1} \cdot \mathrm{d}^{-1}\right)$ & 10 & 4 & 25 & triangular & 30,31 \\
\hline UDDT desiccant volume $\left(\mathrm{mL} \cdot \operatorname{cap}^{-1} \cdot \mathrm{d}^{-1}\right)$ & 200 & 200 & 500 & triangular & 46 \\
\hline UDDT desiccant density $\left(\mathrm{kg} \cdot \mathrm{m}^{-3}\right)$ & 760 & 663 & 977 & triangular & 68,69 \\
\hline UDDT desiccant Mg content (\% of total mass) & 2.24 & 0.8 & 5.62 & triangular & $68,70-74$ \\
\hline UDDT desiccant Ca content (\% of total mass) & 30.34 & 7.42 & 37.16 & triangular & $68,70-74$ \\
\hline Household size $\left(\right.$ cap·household $\left.{ }^{-1}\right)$ & 4 (1.8 st. dev.) & 1 & - & normal & (survey results) \\
\hline Household use density (households $\cdot$ toilet $^{-1}$ ) & 4 & 3 & 5 & uniform & (survey results) \\
\hline Pit latrine capital cost $\left(\right.$ USD toilet $\left.^{-1}\right)$ & 449 & 386 & 511 & uniform & 32 \\
\hline Pit latrine annual oper. cost (\% of capital) & 5 & 2 & 8 & uniform & 35 \\
\hline 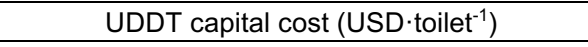 & 553 & 476 & 630 & uniform & 32 \\
\hline UDDT annual operating cost ( $\%$ of capital) & 10 & 5 & 15 & uniform & 75 \\
\hline Toilet lifetime (years) & 8 & 5 & 10 & uniform & 32 \\
\hline \multicolumn{6}{|l|}{ Pit latrine construction materials } \\
\hline Cement $(\mathrm{kg})$ & 700 & - & - & - & 32 \\
\hline Sand $\left(\mathrm{m}^{3}\right)$ & 2.2 & - & - & - & 32 \\
\hline Gravel $\left(\mathrm{m}^{3}\right)$ & 0.8 & - & - & - & 32 \\
\hline Bricks & 54 & - & - & - & 32 \\
\hline Plastic sheet $\left(\mathrm{m}^{2}\right)$ & 16 & - & - & - & 32 \\
\hline Steel $\left(\mathrm{m}^{3}\right)$ & 0.00425 & - & - & - & 32 \\
\hline Excavation $\left(\mathrm{m}^{3}\right)$ & 3.66 & - & - & - & 32 \\
\hline Wood $\left(\mathrm{m}^{3}\right)$ & 0.19 & - & - & - & 32 \\
\hline \multicolumn{6}{|l|}{ UDDT construction materials } \\
\hline Cement $(\mathrm{kg})$ & 200 & - & - & - & 32 \\
\hline Sand $\left(\mathrm{m}^{3}\right)$ & 0.6 & - & - & - & 32 \\
\hline Gravel $\left(\mathrm{m}^{3}\right)$ & 0.2 & - & - & - & 32 \\
\hline Bricks & 682 & - & - & - & 32 \\
\hline Plastic sheet $\left(\mathrm{m}^{2}\right)$ & 4 & - & - & - & 32 \\
\hline Steel $\left(\mathrm{m}^{3}\right)$ & 0.00351 & - & - & - & 32 \\
\hline Stainless steel sheet $\left(\mathrm{m}^{2}\right)$ & 28.05 & - & - & - & 32 \\
\hline Wood $\left(\mathrm{m}^{3}\right)$ & 0.222 & - & - & - & 32 \\
\hline \multicolumn{6}{|l|}{ Material properties } \\
\hline Plastic sheet mass $\left(\mathrm{kg} \cdot \mathrm{m}^{-2}\right)$ & 0.63 & 0.31 & 1.24 & uniform & Colorado Lining International \\
\hline Brick volume $\left(\mathrm{m} 3 \cdot\right.$ brick $\left.^{-1}\right)$ & 0.0024 & - & - & - & (assumption) \\
\hline Brick density $\left(\mathrm{kg} \cdot \mathrm{m}^{-3}\right)$ & 1750 & 1500 & 2000 & uniform & (assumption) \\
\hline Steel sheet mass $\left(\mathrm{kg} \cdot \mathrm{m}^{-2}\right)$ & 2.64 & 2.26 & 3.58 & uniform & Home Depot \\
\hline Gravel bulk density $\left(\mathrm{kg} \cdot \mathrm{m}^{-3}\right)$ & 1600 & 1520 & 1680 & uniform & (assumption) \\
\hline Sand bulk density $\left(\mathrm{kg} \cdot \mathrm{m}^{-3}\right)$ & 1442 & 1281 & 1602 & uniform & (assumption) \\
\hline Steel density $\left(\mathrm{kg} \cdot \mathrm{m}^{-3}\right)$ & 7900 & 7750 & 8050 & uniform & (assumption) \\
\hline \multicolumn{6}{|l|}{ Greenhouse gas unit impact factors } \\
\hline Steel $\left(\mathrm{kg} \mathrm{CO} \mathrm{eq} \cdot \mathrm{kg}^{-1}\right)$ & 2.55 & 2.13 & 3.15 & uniform & 33 \\
\hline Stainless steel $\left(\mathrm{kg} \mathrm{CO} \mathrm{Ca}_{2} \cdot \mathrm{kg}^{-1}\right)$ & 4.33 & 3.07 & 5.5 & uniform & 33 \\
\hline Stainless steel sheet rolling $\left(\mathrm{kg} \mathrm{CO} \mathrm{CO}_{2} \cdot \mathrm{kg}^{-1}\right)$ & 0.65 & 0.58 & 0.71 & uniform & 33 \\
\hline Excavation $\left(\mathrm{kg} \mathrm{CO} \mathrm{Co}_{2} \cdot \mathrm{m}^{-3}\right)$ & 0.53 & 0.51 & 0.55 & uniform & 33 \\
\hline Plastic $\left(\mathrm{kg} \mathrm{CO}_{2} \mathrm{eq} \cdot \mathrm{kg}^{-1}\right)$ & 1.97 & 1.93 & 2.01 & uniform & 33 \\
\hline Gravel $\left(\mathrm{kg} \mathrm{CO}_{2} \mathrm{eq} \cdot \mathrm{kg}^{-1}\right)$ & 0.015 & 0.012 & 0.018 & uniform & 33 \\
\hline Sand $\left(\mathrm{kg} \mathrm{CO} \mathrm{CO}_{2} \mathrm{eq} \mathrm{kg}^{-1}\right)$ & 0.012 & 0.011 & 0.013 & uniform & 33 \\
\hline Cement $\left(\mathrm{kg} \mathrm{CO} \mathrm{CO}_{2} \mathrm{eqg}^{-1}\right)$ & 1.08 & 0.97 & 1.19 & uniform & 33 \\
\hline Bricks $\left(\mathrm{kg} \mathrm{CO} 2 \mathrm{eq} \cdot \mathrm{kg}^{-1}\right)$ & 0.28 & 0.25 & 0.31 & uniform & 33 \\
\hline Wood $\left(\mathrm{kg} \mathrm{CO} \mathrm{CO}_{2} \mathrm{eq} \cdot \mathrm{m}^{-3}\right)$ & 197 & 186 & 208 & uniform & 33 \\
\hline
\end{tabular}


Table S4. Parameter values, ranges, and distributions used in the decentralized storage process stage of the quantitative modeling analysis. Parameters related to latrine pits are used in Scenarios A-B, while those related to urine storage tanks and feces containers are used in Scenario C (Table S1).

\section{Parameters}

Expected Low High Distribution

References

Single latrine pit

\begin{tabular}{|c|c|c|c|c|c|}
\hline Pit volume $\left(\mathrm{m}^{3}\right)$ & 3.66 & - & - & - & (survey results; assumptions) \\
\hline Pit emptying period (yr) & 0.8 & 0.3 & 2.4 & triangular & (survey results; model calculations) \\
\hline Sludge accumulation rate $\left(L \cdot c^{-1} \cdot \mathrm{yr}^{-1}\right)$ & 270 & 100 & 900 & triangular & 31,40 \\
\hline $\mathrm{N}$ leaching ( $\%$ of input) & 13 & 1 & 50 & uniform & $23,26,37-39$ \\
\hline $\mathrm{P}$ leaching (\% of input) & 18 & 0 & 37 & uniform & $23,26,39$ \\
\hline $\mathrm{K}$ leaching ( $\%$ of input) & 21 & 11 & 31 & uniform & 39 \\
\hline $\mathrm{N}_{2} \mathrm{O}$ emission factor (\% of degraded $\mathrm{N}$ ) & 0 & 0 & 0.1 & uniform & 41 \\
\hline $\mathrm{N}$ volatilization (\% of input) & 0.5 & 0 & 1 & uniform & $23,26,37$ \\
\hline $\begin{array}{c}\text { Methane correction factor } \\
\text { (\% anaerobic conversion of degraded COD) }\end{array}$ & 50 & 40 & 60 & triangular & 41 \\
\hline \multicolumn{6}{|l|}{ Urine storage tank } \\
\hline $\mathrm{N}$ volatilization (\% of total) & 5 & 0 & 7 & uniform & 23,61 \\
\hline Struvite conditional $\mathrm{pK}_{\mathrm{sp}}$ & 7.57 & 7.3 & 8.1 & uniform & 60 \\
\hline $\begin{array}{l}\text { Precipitate sludge (\% of precipitate } \\
\text { that settles and can be removed) }\end{array}$ & 75 & 50 & 100 & uniform & 48,58 \\
\hline \multicolumn{6}{|l|}{ Feces container } \\
\hline $\begin{array}{l}\text { Minimum feces moisture content } \\
\text { after extended storage (\%) }\end{array}$ & 10 & 7 & 13 & uniform & 56 \\
\hline $\begin{array}{l}\text { Moisture content exponential } \\
\text { decay rate constant }\left(\mathrm{d}^{-1}\right)\end{array}$ & 0.01 & 0.009 & 0.011 & uniform & 56 \\
\hline $\begin{array}{c}\text { Methane correction factor } \\
\text { (\% anaerobic conversion of degraded COD) }\end{array}$ & 10 & 5 & 15 & triangular & 41 \\
\hline $\mathrm{N}_{2} \mathrm{O}$ emission factor (\% of degraded $\mathrm{N}$ ) & 0 & 0 & 0.1 & uniform & 41 \\
\hline \multicolumn{6}{|l|}{ General parameters } \\
\hline Maximum COD removal ( $\%$ of input) & 70 & 60 & 80 & triangular & 23 \\
\hline Maximum $\mathrm{N}$ degradation (\% of input) & 80 & 70 & 90 & triangular & 23 \\
\hline Container-based collection period (d) & 3.5 & 1 & 9 & triangular & 24 \\
\hline
\end{tabular}


Table S5. Parameter values, ranges, and distributions used in the conveyance process stage of the quantitative modeling analysis.

\begin{tabular}{|c|c|c|c|c|c|}
\hline Parameter & Expected & Low & High & Distribution & References \\
\hline \multicolumn{6}{|l|}{ Tanker truck parameters } \\
\hline $\mathrm{N}$ loss (\% of input) & 2 & 0 & 5 & uniform & (assumption) \\
\hline $\mathrm{P}$ loss ( $\%$ of input) & 2 & 0 & 5 & uniform & (assumption) \\
\hline $\mathrm{K}$ loss ( $\%$ of input) & 2 & 0 & 5 & uniform & (assumption) \\
\hline Mg loss (\% of input) & 2 & 0 & 5 & uniform & (assumption) \\
\hline Ca loss (\% of input) & 2 & 0 & 5 & uniform & (assumption) \\
\hline $\mathrm{C}$ loss (\% of input) & 2 & 0 & 5 & uniform & (assumption) \\
\hline Transport distance $(\mathrm{km})$ & 5 & 2 & 10 & uniform & (assumption) \\
\hline Emission factor $\left(\mathrm{kg} \mathrm{CO} \mathrm{Cq}_{2} \mathrm{t}^{-1} \cdot \mathrm{km}^{-1}\right)$ & 0.194 & 0.0576 & 0.526 & uniform & 33 \\
\hline Base emptying cost for $3-\mathrm{m}^{3}$ volume (UGX) & 80,000 & - & - & - & 42 \\
\hline Base emptying cost for $4.5-\mathrm{m}^{3}$ volume (UGX) & 120,000 & - & - & - & 42 \\
\hline Base emptying cost for $8-\mathrm{m}^{3}$ volume (UGX) & 200,000 & - & - & - & 42 \\
\hline Base emptying cost for $15-\mathrm{m}^{3}$ volume (UGX) & 250,000 & - & - & - & 42 \\
\hline $\begin{array}{l}\text { Additional emptying fee ( } \% \text { of base cost, reflecting } \\
\text { Specific conditions making emptying more difficult) }\end{array}$ & 15 & 0 & 30 & Uniform & truck operators; \\
\hline \multicolumn{6}{|l|}{ Handcart and truck parameters } \\
\hline $\mathrm{N}$ loss (\% of input) & 2 & 0 & 5 & uniform & (assumption) \\
\hline $\mathrm{P}$ loss ( $\%$ of input) & 2 & 0 & 5 & uniform & (assumption) \\
\hline $\mathrm{K}$ loss ( $\%$ of input) & 2 & 0 & 5 & uniform & (assumption) \\
\hline Mg loss (\% of input) & 2 & 0 & 5 & uniform & (assumption) \\
\hline Ca loss ( $\%$ of input) & 2 & 0 & 5 & uniform & (assumption) \\
\hline $\mathrm{C}$ loss ( $\%$ of input) & 2 & 0 & 5 & uniform & (assumption) \\
\hline Transport distance $(\mathrm{km})$ & 5 & 2 & 10 & uniform & (assumption) \\
\hline Emission factor $\left(\mathrm{kg} \mathrm{CO} \mathrm{eq} \cdot \mathrm{t}^{-1} \cdot \mathrm{km}^{-1}\right)$ & 0.194 & 0.0576 & 0.526 & uniform & 33 \\
\hline Handcart collection cost (USD $\left.\cdot \operatorname{cap}^{-1} \cdot d^{-1}\right)$ & 0.010 & 0.004 & 0.015 & uniform & 24 \\
\hline Truck transport cost $\left(U G X \cdot \mathrm{m}^{-3}\right)$ & 23,000 & 17,000 & 30,000 & uniform & (CIDI) \\
\hline
\end{tabular}


Table S6. Parameter values, ranges, and distributions used in the centralized treatment process stage of the quantitative modeling analysis. Sedimentation, anaerobic and facultative lagoon, and unplanted drying bed parameters are used in the existing treatment plant (Scenarios $A$ and $C$ ), while anaerobic digestion, anaerobic filter, and unplanted drying bed parameters are used in the alternative plant (Scenario B).

\section{Parameter}

Sedimentation parameters

Solids residence time (days)

Final solids content (\%)

Solids retention (\% of input)

COD retention (\% of input)

Maximum COD degradation (\% of retained)

Methane correction factor

(\% anaerobic conversion of degraded COD)

Maximum $\mathrm{N}$ degradation (\% of retained $\mathrm{N}$ )

$\mathrm{N}_{2} \mathrm{O}$ emission factor (\% of degraded $\mathrm{N}$ )

$\mathrm{N}$ retention (\% of input)

$\mathrm{P}$ retention (\% of input)

$\mathrm{K}$ retention (\% of input)

Mg retention (\% of input)

Ca retention (\% of input) Volume $\left(\mathrm{m}^{3}\right)$

Length:width ratio

Average width:height ratio

Number of tanks

Columns per side

expected

low

high distribution

References

\section{Anaerobic lagoon parameters
COD removal (\% of input)}

Maximum COD degradation (\% of retained)

Methane correction factor ( $\%$ anaer. conv. of deg. COD) Volume $\left(\mathrm{m}^{3}\right)$

Length $(\mathrm{m})$

Width $(\mathrm{m})$

Number of lagoons

\begin{tabular}{|c|c|}
\hline 45 & \\
14 & \\
50 & \\
\hline 50 & \\
70 & \\
\hline 80 & \\
\hline 80 & \\
0.5 & 0 \\
\hline 6 & 2 \\
19.5 & 8.7 \\
\hline 13 & 2.4 \\
\hline 28 & \\
\hline 44 & \\
1,250 & \\
\hline 3.3 & \\
\hline 3.6 & \\
\hline 2 & \\
12.0 & \\
\hline
\end{tabular}

\begin{tabular}{|c|c}
\hline 30 & \\
\hline 10 & \\
\hline 35 & \\
\hline 35 & \\
\hline 60 & \\
\hline 80 & \\
& \\
\hline 70 & \\
\hline 0.05 & \\
\hline 2.45 & 15.6 \\
\hline 8.75 & 40. \\
\hline 2.45 & 28.2 \\
\hline 19 & \\
\hline 22 & \\
\hline- & \\
\hline 3.0 & 3.5 \\
\hline 3.3 & 3.8 \\
\hline- & \\
- & \\
\hline
\end{tabular}

uniform

\begin{tabular}{c|c|c}
60 & uniform & (Lubigi) \\
20 & uniform & 50 \\
60 & uniform & (Lubigi) \\
60 & uniform & (Lubigi) \\
80 & triangular & 23 \\
\hline 100 & triangular & 44 \\
90 & triangular & ${ }^{23}$ \\
\hline 0.6 & triangular & 44 \\
\hline
\end{tabular}

5.6 triangular

40.2 triangular

Calculations; ${ }^{22}$

\begin{tabular}{r|r} 
& 6 \\
\hline & 19.5 \\
\hline
\end{tabular}

28.2

triangular

Calculations; ${ }^{22}$

Calculations; ${ }^{22}$

\begin{tabular}{l|l|l}
37 & uniform & Calculations; \\
\hline 53 & uniform & Calculations;
\end{tabular}

\begin{tabular}{l|l}
53 & uniform
\end{tabular}

Calculations;

(Lubigi)

\begin{tabular}{c|c}
- & (Lubigi) \\
\hline uniform & (Lubigi) \\
\hline uniform & (Lubigi) \\
\hline
\end{tabular}

\begin{tabular}{l|l}
- & (Lubigi) \\
- & (Lubigi) \\
\hline
\end{tabular}

\begin{tabular}{|c|c|c|}
\hline Length $(\mathrm{m})$ & 4,640 & \\
\hline Width $(\mathrm{m})$ & 65 & \\
\hline Number of lagoons & 30 & \\
\hline
\end{tabular}

Facultative lagoon parameters

COD removal (\% of input)

Maximum COD degradation (\% of retained)

Methane correction factor (\% anaer. conv. of deg. COD)

Maximum $\mathrm{N}$ degradation (\% of input)

$\mathrm{N}_{2} \mathrm{O}$ emission factor (\% of degraded $\mathrm{N}$ )

$P$ removal (\% of input)

Volume $\left(\mathrm{m}^{3}\right)$

Length $(\mathrm{m})$

Width $(\mathrm{m})$

Number of lagoons

\section{Unplanted drying bed parameters \\ Retention time (days)}

Final solids content (\%)

Maximum COD degradation (\% of total)

Methane correction factor (\% anaer. conv. of deg. COD)

Maximum $\mathrm{N}$ degradation (\% of input)

$\mathrm{N}_{2} \mathrm{O}$ emission factor (\% of degraded $\mathrm{N}$ )

Number of covered drying beds

Number of uncovered drying beds

Number of storage beds

Storage bed wall height $(\mathrm{m})$

Covered bed width $(\mathrm{m})$

Covered bed length $(\mathrm{m})$

Drying bed wall height $(\mathrm{m})$

Uncovered bed width $(\mathrm{m})$

Uncovered bed length $(\mathrm{m})$

Columns per side in covered beds

Column height in covered beds $(\mathrm{m})$

Steel column mass $\left(\mathrm{kg} \cdot \mathrm{m}^{-1}\right)$

\begin{tabular}{|c|c|}
\hline 70 & 7 \\
\hline 70 & 6 \\
\hline 20 & \\
\hline 80 & 7 \\
\hline 1.6 & 0. \\
\hline 60 & 5 \\
\hline 11,530 & \\
\hline 170 & \\
\hline 50 & \\
\hline 2 & \\
\hline
\end{tabular}

\begin{tabular}{|l|r}
\hline 60 & 70 \\
\hline 60 & 80 \\
\hline 80 & 100 \\
\hline- & \\
\hline- & \\
\hline- & \\
\hline- & \\
\hline
\end{tabular}

\section{0 triangular}

\begin{tabular}{c|c} 
& \\
\hline Lubiar & Lubi; ${ }^{46}$ \\
\hline ular & 23
\end{tabular}

\begin{tabular}{c|c|c}
80 & triangular & 23 \\
\hline 100 & triangular & 44 \\
- & - & $($ Lubigi) \\
- & - & $($ Lubigi) \\
- & - & (Lubigi) \\
- & - & (Lubigi) \\
\hline
\end{tabular}

Lubigi)

\begin{tabular}{|c|c|c|c|c|}
\hline 180 & 180 & 270 & triangular & (Lubigi) \\
\hline 35 & 30 & 40 & uniform & (Lubigi) \\
\hline 70 & 60 & 80 & triangular & 23 \\
\hline 20 & 0 & 30 & triangular & 44 \\
\hline 80 & 70 & 90 & triangular & 23 \\
\hline 0.5 & 0 & 1.1 & triangular & 44 \\
\hline 19 & - & - & - & (Lubigi) \\
\hline 30 & - & - & - & (Lubigi) \\
\hline 19 & - & - & - & (Lubigi) \\
\hline 1.5 & 1.2 & 1.8 & uniform & (Lubigi) \\
\hline 7 & - & - & - & (Lubigi) \\
\hline 34 & - & - & - & (Lubigi) \\
\hline 0.6 & 0.45 & 0.75 & uniform & (Lubigi) \\
\hline 7 & - & - & - & (Lubigi) \\
\hline 31 & - & - & - & (Lubigi) \\
\hline 7 & - & - & - & (Lubigi) \\
\hline 2.75 & 2.5 & 3 & uniform & (Lubigi) \\
\hline 30 & 23 & 37 & uniform & (Sandeep Steels) \\
\hline
\end{tabular}


Table S6 (cont.)

\section{Parameter}

expected

low

high distribution

References

Anaerobic baffled reactor parameters

Hydraulic retention time (days)

COD removal (\% degraded)

$\mathrm{N}$ removal (\% of input $\mathrm{N})$

Length $(\mathrm{m})$

Width (m)

Height (m)

Baffles

Additional concrete for receiving basin, etc. (\%)

\begin{tabular}{|c|c|c|c|c|}
\hline 3 & 1 & 5 & uniform & CIDI; $^{21,50}$ \\
\hline 93 & 83 & 99 & uniform & ${ }^{21}$ \\
\hline 7 & 0 & 15 & uniform & 50 \\
\hline 17 & - & - & - & $(\mathrm{CIDI})$ \\
\hline 5 & - & - & - & (CIDI) \\
\hline 2.5 & 2.0 & 3.0 & uniform & (CIDI) \\
\hline 2 & - & - & - & (CIDI) \\
\hline 2 & 20 & 30 & Uniform & (assumption) \\
\hline
\end{tabular}

\section{Liquid treatment bed parameters}

Hydraulic retention time (days)

COD removal (\% degraded)

Methane correction factor ( $\%$ anaer. conv. of deg. COD)

Length $(\mathrm{m})$

Width $(\mathrm{m})$

Height $(m)$

\begin{tabular}{|c|c|c|c|c|}
\hline 3 & 1 & 5 & uniform & CIDI; 21,50 \\
\hline 70 & 60 & 80 & triangular & 50 \\
\hline 80 & 80 & 100 & triangular & ${ }^{44}$ \\
\hline 17.49 & - & - & - & (CIDI) \\
\hline 12.415 & - & - & - & (CIDI) \\
\hline 1.5 & 1.2 & 1.8 & Uniform & (CIDI) \\
\hline
\end{tabular}

Alternate drying beds parameters (other parameters are the same as existing drying beds)

\begin{tabular}{|c|c|c|c|c|c|}
\hline Final solids content (\%) & 55 & 40 & 70 & uniform & 50 \\
\hline Length $(\mathrm{m})$ & 22.345 & - & - & - & (CIDI) \\
\hline Width $(\mathrm{m})$ & 19.33 & - & - & - & (CIDI) \\
\hline Height (m) & 0.60 & 0.45 & 0.75 & Uniform & (CIDI) \\
\hline \multicolumn{6}{|l|}{ General parameters } \\
\hline Methane energetic content $\left(\mathrm{kJ} \cdot \mathrm{mol} \mathrm{CH}_{4}{ }^{-1}\right)$ & 803 & 802 & 870 & triangular & $21,76,77$ \\
\hline Sewer flow to existing plant $\left(\mathrm{m}^{3} \cdot \mathrm{d}^{-1}\right)$ & 2,750 & 2,500 & 3,000 & uniform & (Lubigi) \\
\hline Latrine sludge flow to existing plant $\left(\mathrm{m}^{3} \cdot \mathrm{d}^{-1}\right)$ & 500 & - & - & - & (Lubigi) \\
\hline Latrine sludge flow to alternative plant $\left(\mathrm{m}^{3} \cdot \mathrm{d}^{-1}\right)$ & 60 & - & - & - & (CIDI) \\
\hline Concrete thickness $(\mathrm{m})$ & 0.3 & 0.15 & 0.45 & uniform & (assumption) \\
\hline Plastic liner mass $\left(\mathrm{kg} \cdot \mathrm{m}^{-2}\right)$ & 0.63 & 0.31 & 1.24 & uniform & $\begin{array}{l}\text { Colorado Lining } \\
\text { International }\end{array}$ \\
\hline Gravel bulk density $\left(\mathrm{kg} \cdot \mathrm{m}^{-3}\right)$ & 1600 & 1520 & 1680 & uniform & \\
\hline Roof slope (degrees) & 20 & 10 & 30 & uniform & (assumption) \\
\hline Roof mass $\left(\mathrm{kg} \cdot \mathrm{m}^{-2}\right)$ & 2.64 & 2.26 & 3.58 & uniform & Home Depot \\
\hline Capital cost of existing plant (USD) & $18,606,700$ & - & - & - & (Lubigi) \\
\hline Electricity demand of existing plant $\left(\mathrm{kWh} \cdot \mathrm{yr}^{-1}\right)$ & 57,120 & - & - & - & (Lubigi) \\
\hline Staff of existing plant (people) & 12 & - & - & - & (Lubigi) \\
\hline Salary for existing plant staff $\left(\right.$ million UGX $\operatorname{cap}^{-1} \cdot$ month $^{-1}$ ) & 3.5 & 1 & 5 & - & (Lubigi) \\
\hline Capital cost of alternative plant (USD) & 337,140 & 303,426 & 370,854 & triangular & (CIDI) \\
\hline $\begin{array}{l}\text { Electricity demand of alternative plant } \\
\qquad\left(\mathrm{kWh} \cdot \mathrm{yr}^{-1}\right)\end{array}$ & 6,854 & - & - & - & (assumption) \\
\hline Skilled staff of alternative plant (people) & 5 & - & - & - & (CIDI) \\
\hline Unskilled staff of alternative plant (people) & 5 & 0 & 10 & uniform & (CIDI) \\
\hline Salary, skilled alt. plant staff (million UGX $\left.\operatorname{cap}^{-1} \cdot \mathrm{month}^{-1}\right)$ & 5 & - & - & - & (CIDI) \\
\hline Salary, unskilled alt. plant staff (million UGX $\operatorname{cap}^{-1} \cdot \mathrm{month}^{-1}$ ) & 0.75 & 0.50 & 1.00 & uniform & $(\mathrm{CIDI})$ \\
\hline Electricity cost $\left(\mathrm{USD} \cdot \mathrm{kWh}^{-1}\right)$ & 0.17 & 0.08 & 0.21 & triangular & (Umeme, 2019) \\
\hline Electricity $\mathrm{GHG}$ impact factor $\left(\mathrm{kg} \mathrm{CO} \mathrm{CO}_{2} \mathrm{eq} \cdot \mathrm{kWh}^{-1}\right)$ & 0.15 & 0.106 & 0.121 & uniform & 33,47 \\
\hline Existing plant lifetime (yr) & 8 & 8 & 11 & triangular & (Lubigi) \\
\hline Alternative plant lifetime (yr) & 50 & 45 & 55 & Triangular & (CIDI) \\
\hline Sewered population served by existing plant & 40,000 & 30,000 & 50,000 & uniform & (Lubigi) \\
\hline $\begin{array}{c}\text { Population producing latrine sludge } \\
\text { treated by existing plant }\end{array}$ & 416,667 & 375,000 & 458,333 & triangular & $\begin{array}{l}\text { Lubigi, CIDI, } \\
\text { calculations }\end{array}$ \\
\hline $\begin{array}{l}\text { Population potentially served by } \\
\text { alternative sludge treatment plant }\end{array}$ & 50,000 & 45,000 & 55,000 & triangular & (CIDI) \\
\hline \multicolumn{6}{|l|}{ Greenhouse gas unit impact factors } \\
\hline Concrete $\left(\mathrm{kg} \mathrm{CO} 2 \mathrm{eq} \cdot \mathrm{m}^{-3}\right)$ & 300 & 218 & 385 & uniform & 33 \\
\hline Stainless steel $\left(\mathrm{kg} \mathrm{CO} 2 \mathrm{eq} \cdot \mathrm{kg}^{-1}\right)$ & 4.33 & 3.07 & 5.5 & uniform & 33 \\
\hline Stainless steel sheet rolling $\left(\mathrm{kg} \mathrm{CO} \mathrm{eq} \cdot \mathrm{kg}^{-1}\right)$ & 0.65 & 0.58 & 0.71 & uniform & 33 \\
\hline Excavation $\left(\mathrm{kg} \mathrm{CO} 2 \mathrm{eq} \cdot \mathrm{m}^{-3}\right)$ & 0.53 & 0.51 & 0.55 & uniform & 33 \\
\hline Plastic liner $\left(\mathrm{kg} \mathrm{CO} 2 \mathrm{eq} \mathrm{kg}^{-1}\right)$ & 1.97 & 1.93 & 2.01 & uniform & 33 \\
\hline Gravel $\left(\mathrm{kg} \mathrm{CO} 2 \mathrm{eq} \cdot \mathrm{kg}^{-1}\right)$ & 0.015 & 0.012 & 0.018 & uniform & 33 \\
\hline
\end{tabular}


Table S7. Parameter values, ranges, and distributions used in the reuse/disposal process stage of the quantitative modeling analysis.

Parameter

Expected Low High Distribution

References

Crop application parameters

\begin{tabular}{|c|c|c|c|c|c|}
\hline $\begin{array}{l}\text { Ammonia transfer losses } \\
\text { (\% of input ammonia) }\end{array}$ & 5 & 0 & 10 & uniform & 48 \\
\hline $\begin{array}{c}\mathrm{N} \text { transfer losses } \\
(\% \text { of non-ammonia } \mathrm{N})\end{array}$ & 2 & 0 & 5 & uniform & (assumption) \\
\hline $\mathrm{P}$ transfer losses (\% of input) & 2 & 0 & 5 & uniform & (assumption) \\
\hline $\mathrm{K}$ transfer losses (\% of input) & 2 & 0 & 5 & uniform & (assumption) \\
\hline Mg transfer losses (\% of input) & 2 & 0 & 5 & uniform & (assumption) \\
\hline Ca transfer losses ( $\%$ of input) & 2 & 0 & 5 & uniform & (assumption) \\
\hline C transfer losses (\% of input) & 2 & 0 & 5 & uniform & (assumption) \\
\hline $\mathrm{N}$ fertilizer price (USD $\cdot$ tonne $\mathrm{N}^{-1}$ ) & 1,507 & 1,164 & 2,296 & uniform & Kampala retailers (urea); ${ }^{49}$ \\
\hline P fertilizer price (USD·tonne $\mathrm{P}^{-1}$ ) & 3,983 & 2,619 & 6,692 & uniform & Kampala retailers (TSP); ${ }^{49}$ \\
\hline $\mathrm{K}$ fertilizer price (USD·tonne $\mathrm{K}^{-1}$ ) & 1,333 & 1,214 & 1,474 & uniform & Kampala retailers (MOP); ${ }^{49}$ \\
\hline $\begin{array}{c}\text { Sludge fertilizer discount factor } \\
\text { (nutrient price in sludge } \text { price } \\
\text { in commercial fertilizer }{ }^{-1} \text { ) }\end{array}$ & 0.25 & 0.1 & 0.4 & uniform & Lubigi; model calculations \\
\hline $\begin{array}{c}\mathrm{N} \text { fertilizer emissions } \\
\left(\mathrm{kg} \mathrm{CO}_{2} \text { eq } \cdot \mathrm{kg} \mathrm{N}^{-1} \text { fertilizer produced }{ }^{-1}\right)\end{array}$ & 5.4 & 1.8 & 8.9 & triangular & 33 \\
\hline $\begin{array}{c}\mathrm{P} \text { fertilizer emissions } \\
\left(\mathrm{kg} \mathrm{CO}_{2} \text { eq } \cdot \mathrm{kg} \mathrm{P}^{\mathrm{P}} \text { fertilizer produced }{ }^{-1}\right)\end{array}$ & 4.9 & 4.3 & 5.4 & triangular & 33 \\
\hline $\begin{array}{c}\mathrm{K} \text { fertilizer emissions } \\
\left(\mathrm{kg} \mathrm{CO}_{2} \text { eq } \cdot \mathrm{kg} \mathrm{K}^{-1} \text { fertilizer produced }{ }^{-1}\right)\end{array}$ & 1.5 & 1.1 & 2 & triangular & 33 \\
\hline \multicolumn{6}{|l|}{ Biogas fuel parameters } \\
\hline Biogas transfer losses (\%) & 10 & 0 & 20 & uniform & 51 \\
\hline LPG selling price $\left(U G X \cdot \mathrm{kg}^{-1}\right)$ & 6,500 & 6,077 & 6,667 & uniform & (Kampala retailers) \\
\hline LPG specific energy $\left(\mathrm{MJ} \cdot \mathrm{kg}^{-1}\right)$ & 50 & 49.5 & 50.4 & uniform & 52 \\
\hline LPG emissions ( $\mathrm{kg} \mathrm{CO} \mathrm{eq} \cdot \mathrm{kg} \mathrm{LPG}^{-1}$ ) & 3 & 2.93 & 3.05 & uniform & 55 \\
\hline
\end{tabular}




\section{Theme C. Household surveys in Bwaise, Uganda}

Section S7. Survey data collection. As part of a broader effort to characterize water, sanitation, and health conditions within the settlement, we carried out a household survey in May 2018. Over a period of nine days, ten trained enumerators from Makerere University visited 897 households and conducted 844 surveys among those giving informed consent. This sample size represented approximately $4 \%$ of all households across Bwaise's three parishes (Bwaise I, II, and III; Figure S2), ${ }^{78}$ resulting in a margin of error of $\pm 3 \%$ with a $95 \%$ confidence level using conservative assumptions for proportional responses. ${ }^{27,79}$

To ensure adequate geographic representation, we collaborated with CIDI and community leaders to identify nine zones within the settlement, and enumerators visited one zone each day. Within a zone, 3-5 community leaders (including some from outside that zone) accompanied enumerators and randomly selected households. CIDI held a meeting with all community leaders the day before the survey began, during which CIDI staff reviewed the purpose of the study, explained household sampling procedures, and emphasized the need for random selection. Each day, 2-3 CIDI staff familiar with the community were onsite to coordinate and oversee household selection, ensuring community leaders and enumerators were identifying households appropriately, with an adequate spatial distribution and no favoritism. After identifying a household, the community leader introduced the enumerator to the female household head or primary caregiver, because this survey also informed another study characterizing pathogen exposure routes and risks relevant for child health; accordingly, 92\% of all respondents were women. Enumerators administered the survey by reading questions from a questionnaire (translating into the local language) and recording responses on an iPad. Survey questions covered various topics including child health, water, sanitation, energy, agriculture, and diet (Table S11). Human subjects research approvals were obtained from UIUC and MU Institutional Review Boards, and the Uganda National Council for Science and Technology approved the study.

Section S8. Survey regression analysis. Part of the survey was employed to identify factors affecting users' satisfaction with existing sanitation facilities. Satisfaction level was represented with an ordinal categorical variable (i.e., in response to the question "Are you satisfied with the toilet facility?", participants answered "no", "partially", or "yes"), and those who answered "no" or "partially" were asked why they were unsatisfied. We used the proportional odds model for ordered logistic regression (an extension of the binary logistic model) ${ }^{80}$ to evaluate associations between satisfaction level and other survey variables reflecting aspects of the sanitation system (e.g., toilet facility type, sharing). We removed any "Don't know" responses prior to analysis. The key outputs of ordered logistic regression are proportional odds ratios estimated for each survey response. These ratios represent the difference in outcome (satisfaction level, in this case) between one survey response and a reference (baseline) response for the same question (for example, a ratio less than one shows a response is typically associated with lower satisfaction levels than the reference response, while a ratio larger than one indicates the opposite).

As a preliminary screening step to identify variables for inclusion in our final multivariate model, we employed bivariate regression to evaluate unadjusted relationships between satisfaction and each of 45 individual variables (Table S8) representing aspects of existing sanitation systems and environmental conditions (e.g., toilet facility type, flooding) or potential sources of confounding (e.g., due to differences in parish or ownership of household assets, which might relate to wealth disparities). We used household ownership of assets (e.g., televisions, computers) as approximate indicators of wealth and income because over half of respondents did not report their monthly household income, either because they did not know or were unwilling to share. For 
example, among households that did report monthly income, those owning computers had a median income three times larger than those without a computer. When performing regression analyses, each categorical variable with more than two possible responses was coded using multiple dichotomous dummy variables, ${ }^{81}$ with the reference response (where all dummy variables equal 0) being the most common survey response. As such, each dummy variable represents a deviation from typical conditions. To cross-check bivariate regression results, we also performed Pearson's Chi-squared tests as a separate measure of the likelihood that a categorical variable relates to satisfaction level (Tables S8-S9). ${ }^{82}$

From these preliminary screening models, we identified variables to incorporate in a final multivariate regression analysis. We included variables where $p<0.20$ in either the preliminary bivariate regression or Chi-squared test. ${ }^{83}$ To avoid any substantial loss in statistical power due to missing responses (e.g., because survey participants did not know or wish to respond), any variables with $<680$ valid responses (approximately $80 \%$ of the total number of surveys) were omitted. These criteria resulted in a final regression analysis that assessed associations between satisfaction levels and 22 potentially explanatory variables (Table S8) - five reflecting aspects of existing sanitation systems and environmental conditions, and 17 that account for potential confounding. Additionally, we performed two alternative multivariate analyses to assess whether omitting certain parameters substantially changed other variables' regression coefficients. In these two alternatives, selection criteria were further constrained to include only variables with bivariate regressions where $p<0.10$ (13 variables included) or $p<0.05$ (10 variables included). 
Combined model including parameters with:

0 individual model $p<0.05 \Delta \quad$ individual model $p<0.10 \quad \square \quad$ individual model $p<0.20$

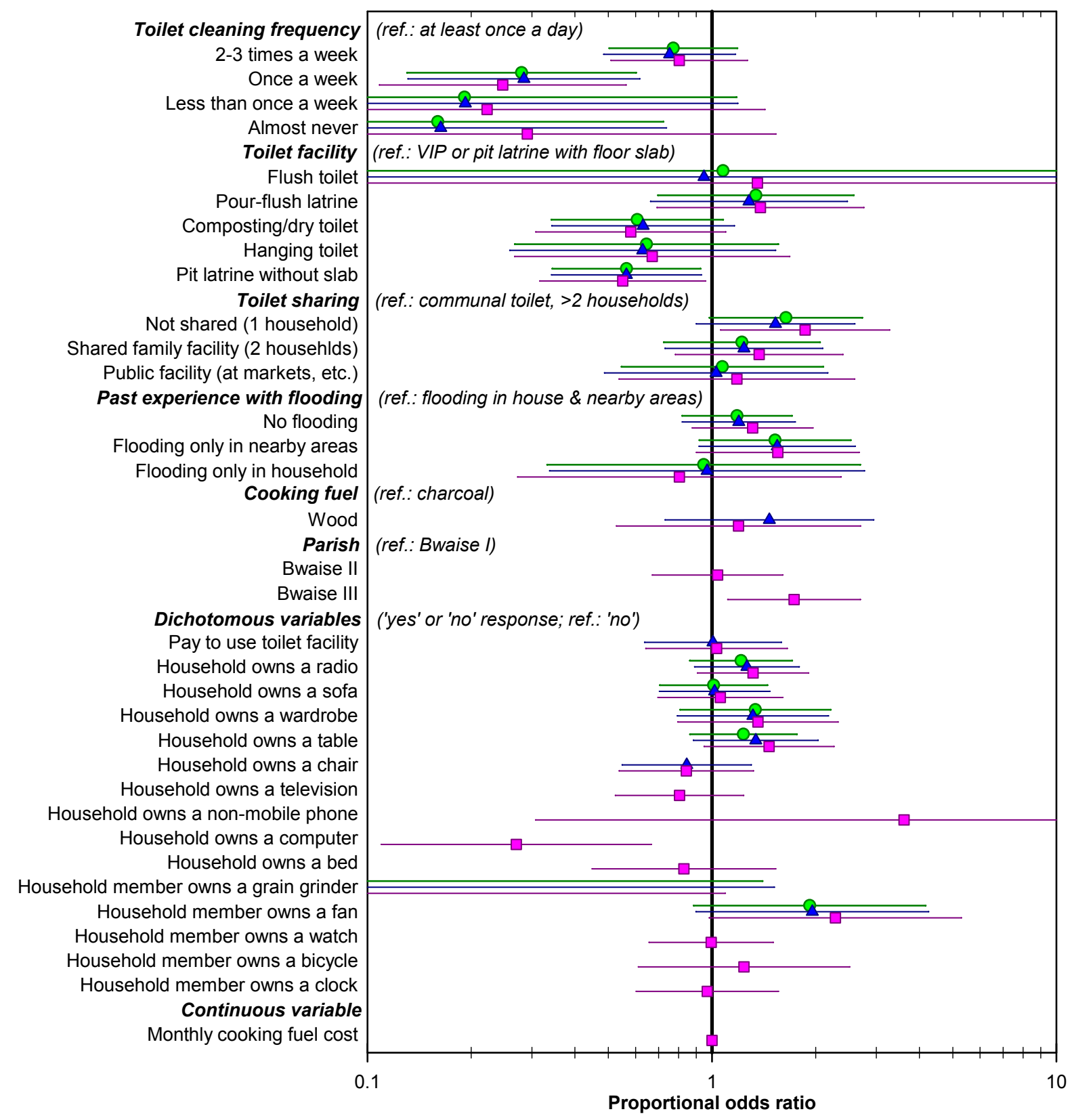

Figure S6. Sensitivity analysis showing how removing parameters from the final regression model affects odds ratios. The primary model discussed in the main text corresponds to the odds ratios shown as magenta squares and includes all variables with bivariate model $p<0.20$. Two additional models, including only parameters with bivariate model $p<0.10$ (blue triangles) and $p<0.05$ (green circles), show how the remaining odds ratios change when other variables are removed. In most cases, values remain similar, suggesting that these results are relatively insensitive to the inclusion or exclusion of other parameters. 
Table S8. Results of preliminary screening tests to identify variables for inclusion in full multivariate regression analysis of survey results. Each bivariate regression model and Chisquare test assessed the relationship between the listed variable and sanitation satisfaction levels. Variables shown with gray cell shading were excluded from the final multivariate regression model, because neither the bivariate regression nor the Chi-square test resulted in $p<0.20$. Variables with $<700$ valid survey responses were also omitted to avoid any substantial loss in the final model's statistical power. Additional variables were removed from the two additional regression models used to test the sensitivity of coefficient values. Only variables with bivariate regression $p<0.10$ or $p<0.05$ were included in these two additional models.

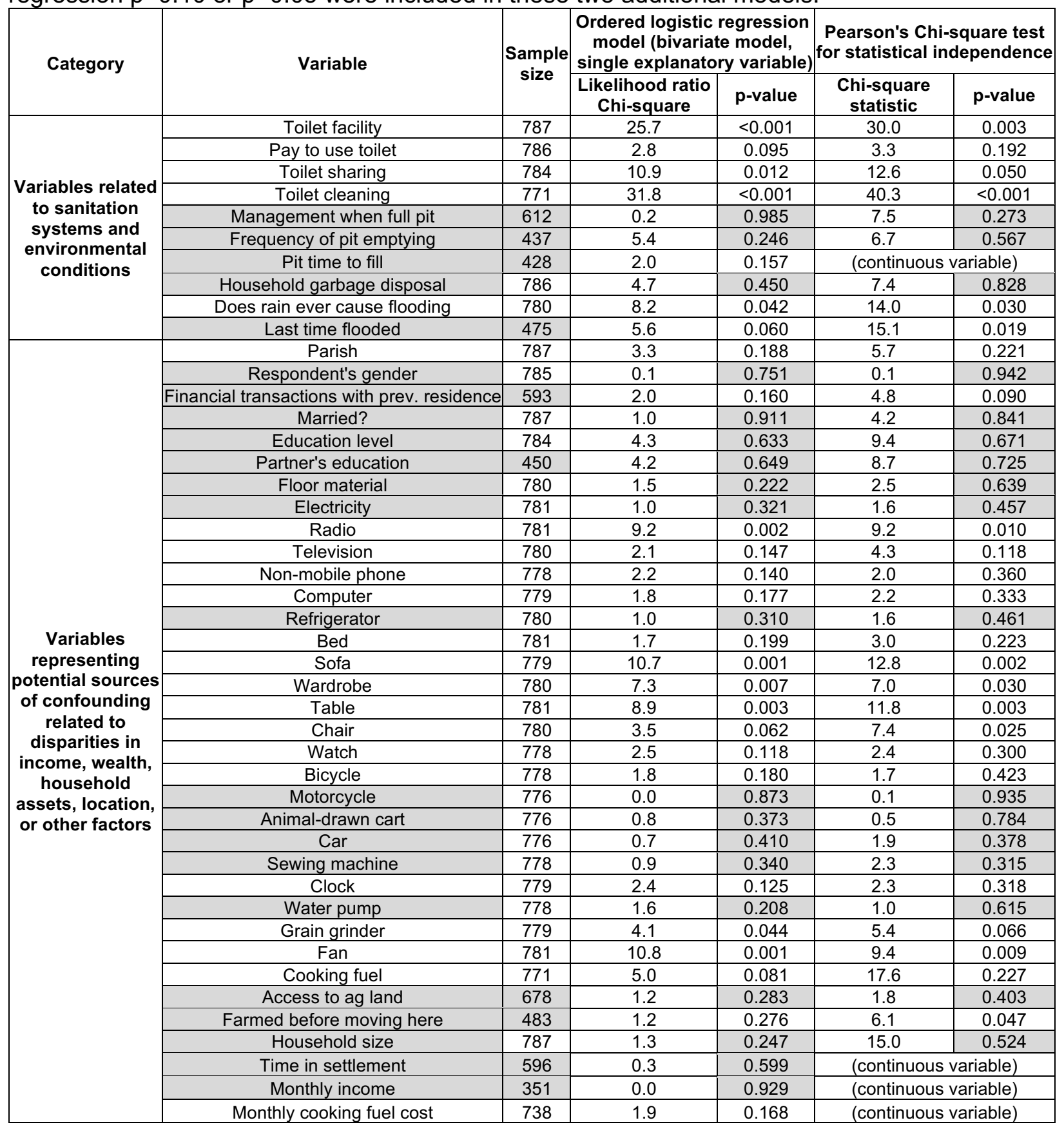


Table S9. Examples of relationships identified through analyzing standardized residuals in the contingency tables from Chi-square tests.

\begin{tabular}{|c|c|c|l|}
\hline \multirow{2}{*}{ Variable } & $\begin{array}{c}\text { Pearson's Chi-square test for } \\
\text { statistical independence }\end{array}$ & \multicolumn{1}{|c|}{ Key findings from standardized residual analysis of Chi-square } \\
\cline { 2 - 3 } contingency tables & $\begin{array}{c}\text { Chi-square } \\
\text { statistic }\end{array}$ & p-value & \\
\hline Toilet facility & 30.0 & 0.003 & $\begin{array}{l}\text { Higher satisfaction for pour-flush and VIP latrine with floor slab; lower for } \\
\text { composting latrines, open defecation, and pit latrines without floor slab }\end{array}$ \\
\hline Toilet sharing & 12.6 & 0.050 & Higher satisfaction for facilities that are not shared \\
\hline Toilet cleaning & 40.3 & $<0.001$ & $\begin{array}{l}\text { Higher satisfaction for facilities cleaned at least once a day; } \\
\text { lower from cleaning once a week or almost never }\end{array}$ \\
\hline $\begin{array}{c}\text { Does rain ever } \\
\text { cause flooding }\end{array}$ & 14.0 & 0.030 & Lower satisfaction when flooding within and around households \\
\hline Radio & 9.2 & 0.010 & Higher satisfaction among households with a radio \\
\hline Sofa & 12.8 & 0.002 & Higher satisfaction among households with a sofa \\
\hline Wardrobe & 7.0 & 0.030 & Higher satisfaction among households with a wardrobe \\
\hline Table & 11.8 & 0.003 & Higher satisfaction among households with a table \\
\hline Chair & 7.4 & 0.025 & Lower satisfaction among households without a chair \\
\hline Fan & 9.4 & 0.009 & Higher satisfaction among households with a fan \\
\hline $\begin{array}{c}\text { Farmed before } \\
\text { moving here }\end{array}$ & 6.1 & 0.047 & Lower satisfaction may be correlated with farming before moving here \\
\hline
\end{tabular}


Table S10. Summarized results from the household survey in Bwaise. Results for all questions are included, and results are summarized (with no identifying information attached) to protect the confidentiality of respondents.

(Table S10 is included as an Excel spreadsheet:

Trimmer_et_al_-_Bwaise_sanitation_tradeoffs_Table_S10.x/sx) 
Table S11. Sample questions from the household survey deployed in Bwaise, Uganda. The survey contained a total of 108 questions. Where appropriate, questions were modeled after those in Demographic and Health Surveys (USAID), Living Standards Measurement Surveys (World Bank), and Multiple Indicator Cluster Surveys (UNICEF). Unless otherwise specified, participants were not prompted with possible responses.

\begin{tabular}{|c|}
\hline Household demographics \\
\hline Q7. How long have you lived in this settlement? \\
\hline Q13. What is your current occupation? \\
\hline Child health \\
\hline Q18. What illness do you think that children under the age of 5 in the neighborhood suffer from most often? \\
\hline $\begin{array}{l}\text { Q22. Have you observed your child putting soil, mud, clay, or sand into his or her mouth in the past } 7 \text { days? } \\
\text { Possible responses: yes, no (other than normal hand to mouth contact), no (not at all), don't know }\end{array}$ \\
\hline Water \\
\hline Q43. What is the current main source of drinking water for members of your household? \\
\hline Q45. How much water (i.e., how many jerry cans) do you collect for your household each day from this source? \\
\hline $\begin{array}{l}\text { Q50. How safe do you think it is to drink water directly from your main drinking water source? } \\
\text { Possible responses: very safe, somewhat safe, unsafe, don't know }\end{array}$ \\
\hline Sanitation \\
\hline Q63. What kind of toilet facility does this household use? \\
\hline Q64. How many households share this toilet? \\
\hline $\begin{array}{l}\text { Q67. Are you satisfied with the toilet facility? } \\
\text { Possible responses: yes, partially, no, don't know }\end{array}$ \\
\hline $\begin{array}{l}\text { Q69. How are excreta managed when the toilet facility is full? } \\
\text { Possible responses: pit is filled in, pit is left open, contents are emptied and treated, contents are emptiec } \\
\text { and dumped on open land or water }\end{array}$ \\
\hline Q72. How long does it take for the toilet facility to fill? \\
\hline $\begin{array}{l}\text { Q80. Does rain ever cause flooding of your compound and/or household? } \\
\text { Possible responses: yes (in house and nearby), yes (only in house), yes (only nearby), no, don't know }\end{array}$ \\
\hline Household assets \\
\hline Q83. What material is the household floor made of? \\
\hline Q84. Does your household have X? (e.g., electricity, television, computer, refrigerator) \\
\hline Energy \\
\hline Q88. What type of fuel does your household use for cooking? \\
\hline Q92. How much does your household spend on cooking fuel every month (if not collecting own firewood)? \\
\hline Agriculture \\
\hline Q93. Does your household have access to agricultural land for your own cultivation? \\
\hline Q97. What crops do you grow? (e.g., maize, matooke, sweet potatoes, beans) \\
\hline Q98. Can you estimate how much fertilizer your household bought or received last year? \\
\hline Diet \\
\hline Q106. In the past 7 days, what foods did your household consume? (e.g., maize, matooke, sweet potatoes) \\
\hline $\begin{array}{l}\text { Q108. Before consuming food that is eaten uncooked, which of the following is done to the food item? } \\
\text { Possible responses: rinsed with water, nothing, other (specify), don't know }\end{array}$ \\
\hline
\end{tabular}




\section{Supporting References}

(1) Trimmer, J. T.; Miller, D. C.; Byrne, D. M.; Lohman, H. A. C.; Banadda, N.; Baylis, K.; Cook, S. M.; Cusick, R. D.; Jjuuko, F.; Margenot, A. J.; Zerai, A.; Guest, J. S. ReEnvisioning Sanitation as a Human-Derived Resource System. Environ. Sci. Technol. accepted.

(2) Hauke, J.; Kossowski, T. Comparison of Values of Pearson's and Spearman's Correlation Coefficient on the Same Sets of Data. Quaest. Geogr. 2011, 30 (2), 87-93. https://doi.org/10.2478/v10117-011-0021-1.

(3) Maurer, M.; Bufardi, A.; Tilley, E.; Zurbrügg, C.; Truffer, B. A Compatibility-Based Procedure Designed to Generate Potential Sanitation System Alternatives. J. Environ. Manage. 2012, 104, 51-61. https://doi.org/10.1016/j.jenvman.2012.03.023.

(4) Spuhler, D.; Scheidegger, A.; Maurer, M. Generation of Sanitation System Options for Urban Planning Considering Novel Technologies. Water Res. 2018, 145, 259-278. https://doi.org/10.1016/j.watres.2018.08.021.

(5) Python Downloads https://www.python.org/ (accessed Jul 26, 2020).

(6) Spyder: The Scientific Python Development Environment https://www.spyder-ide.org/ (accessed Jul 26, 2020).

(7) Trimmer, J. T. QSD-for-WaSH/Bwaise-sanitation-alternatives https://github.com/QSD-forWaSH/Bwaise-sanitation-alternatives (accessed Jul 28, 2020).

(8) Trimmer, J. T.; Cusick, R. D.; Guest, J. S. Amplifying Progress toward Multiple Development Goals through Resource Recovery from Sanitation. Environ. Sci. Technol. 2017, 51 (18), 10765-10776. https://doi.org/10.1021/acs.est.7b02147.

(9) Mihelcic, J. R.; Fry, L. M.; Shaw, R. Global Potential of Phosphorus Recovery from Human Urine and Feces. Chemosphere 2011, 84 (6), 832-839. https://doi.org/10.1016/j.chemosphere.2011.02.046.

(10) FAOSTAT. Food and Agricultural Organization statistics division http://faostat3.fao.org/home/E (accessed Apr 21, 2018).

(11) FAO. Global Food Losses and Food Waste; Food and Agricultural Organization of the United Nations: Rome, 2011.

(12) Jönsson, H.; Stinzing, A. R.; Vinnerås, B.; Salomon, E. Guidelines on the Use of Urine and Faeces in Crop Production; Stockholm Environment Institute: Stockholm, Sweden, 2004.

(13) FAO. Food Energy - Methods of Analysis and Conversion Factors; Food and Nutrition Paper 77; Food and Agricultural Organization of the United Nations: Rome, 2003.

(14) Holbrook, J. T.; Patterson, K. Y.; Bodner, J. E.; Douglas, L. W.; Veillon, C.; Kelsay, J. L.; Mertz, W.; Smith, J. C. Sodium and Potassium Intake and Balance in Adults Consuming Self-Selected Diets. Am. J. Clin. Nutr. 1984, 40 (4), 786-793.

(15) Kodama, N.; Morikuni, E.; Matsuzaki, N.; Yoshioka, Y. H.; Takeyama, H.; Yamada, H.; Kitajima, H.; Nishimuta, M. Sodium and Potassium Balances in Japanese Young Adults. J. Nutr. Sci. Vitaminol. (Tokyo) 2005, 51 (3), 161-168.

(16) Rittmann, B. E.; Mayer, B.; Westerhoff, P.; Edwards, M. Capturing the Lost Phosphorus. Chemosphere 2011, 84 (6), 846-853.

https://doi.org/10.1016/j.chemosphere.2011.02.001.

(17) Richert, A.; Gensch, R.; Jönsson, H.; Stenström, T.-A.; Dagerskog, L. Practical Guidance on the Use of Urine in Crop Production; Stockholm Environment Institute: Stockholm, Sweden, 2010.

(18) Friedler, E.; Butler, D.; Alfiya, Y. Wastewater Composition. In Source Separation and Decentralization for Wastewater Management; Larsen, T. A., Udert, K. M., Lienert, J., Eds.; IWA Publishing: London, UK, 2013; pp 241-258. 
(19) McCarty, P. L.; Bae, J.; Kim, J. Domestic Wastewater Treatment as a Net Energy Producer-Can This Be Achieved? Environ. Sci. Technol. 2011, 45 (17), 7100-7106. https://doi.org/10.1021/es2014264.

(20) Hall, K. D.; Heymsfield, S. B.; Kemnitz, J. W.; Klein, S.; Schoeller, D. A.; Speakman, J. R. Energy Balance and Its Components: Implications for Body Weight Regulation. Am. J. Clin. Nutr. 2012, 95 (4), 989-994. https://doi.org/10.3945/ajen.112.036350.

(21) Tchobanoglous, G.; Stensel, H. D.; Tsuchihashi, R.; Burton, F.; Abu-Orf, M.; Bowden, G.; Pfrang, W. Wastewater Engineering: Treatment and Resource Recovery, 5th ed.; Metcalf \& Eddy, Inc., AECOM, McGraw-Hill: New York, 2014.

(22) Rose, C.; Parker, A.; Jefferson, B.; Cartmell, E. The Characterization of Feces and Urine: A Review of the Literature to Inform Advanced Treatment Technology. Crit. Rev. Environ. Sci. Technol. 2015, 45 (17), 1827-1879. https://doi.org/10.1080/10643389.2014.1000761.

(23) Orner, K. D.; Mihelcic, J. R. A Review of Sanitation Technologies to Achieve Multiple Sustainable Development Goals That Promote Resource Recovery. Environ. Sci. Water Res. Technol. 2018, 4 (1), 16-32. https://doi.org/10.1039/C7EW00195A.

(24) Schmitt, R. J. P.; Morgenroth, E.; Larsen, T. A. Robust Planning of Sanitation Services in Urban Informal Settlements: An Analytical Framework. Water Res. 2017, 110, 297-312. https://doi.org/10.1016/j.watres.2016.12.007.

(25) Myhre, G.; Shindell, D.; Bréon, F.-M.; Collins, W.; Fuglestvedt, J.; Huang, J.; Koch, D.; Lamarque, J.-F.; Lee, D.; Mendoza, B.; Nakajima, T.; Robock, A.; Stephens, G.;

Takemura, T.; Zhang, H. Anthropogenic and Natural Radiative Forcing. In Climate Change 2013: The Physical Science Basis. Contribution of Working Group I to the Fifth Assessment Report of the Intergovernmental Panel on Climate Change; Stocker, T. F., Qin, D., Plattner, G.-K., Tignor, M., Allen, S. K., Boschung, J., Nauels, A., Xia, Y., Bex, V., Midgley, P. M., Eds.; Cambridge University Press: Cambridge, United Kingdom and New York, NY, USA, 2013.

(26) Nyenje, P. M.; Foppen, J. W.; Kulabako, R.; Muwanga, A.; Uhlenbrook, S. Nutrient Pollution in Shallow Aquifers Underlying Pit Latrines and Domestic Solid Waste Dumps in Urban Slums. J. Environ. Manage. 2013, 122 (Supplement C), 15-24. https://doi.org/10.1016/j.jenvman.2013.02.040.

(27) Katukiza, A. Y.; Ronteltap, M.; Oleja, A.; Niwagaba, C. B.; Kansiime, F.; Lens, P. N. L. Selection of Sustainable Sanitation Technologies for Urban Slums - A Case of Bwaise III in Kampala, Uganda. Sci. Total Environ. 2010, 409 (1), 52-62.

https://doi.org/10.1016/j.scitotenv.2010.09.032.

(28) Friedler, E.; Brown, D. M.; Butler, D. A Study of WC Derived Sewer Solids. Water Sci. Technol. 1996, 33 (9), 17-24.

(29) Almeida, M. C.; Butler, D.; Friedler, E. At-Source Domestic Wastewater Quality. Urban Water 1999, 1 (1), 49-55. https://doi.org/10.1016/S1462-0758(99)00008-4.

(30) Fry, L. M.; Mihelcic, J. R.; Watkins, D. W. Water and Nonwater-Related Challenges of Achieving Global Sanitation Coverage. Environ. Sci. Technol. 2008, 42 (12), 4298-4304. https://doi.org/10.1021/es7025856.

(31) Strande, L.; Schoebitz, L.; Bischoff, F.; Ddiba, D.; Okello, F.; Englund, M.; Ward, B. J.; Niwagaba, C. B. Methods to Reliably Estimate Faecal Sludge Quantities and Qualities for the Design of Treatment Technologies and Management Solutions. J. Environ. Manage. 2018, 223, 898-907. https://doi.org/10.1016/j.jenvman.2018.06.100.

(32) Lohman, H. A. C.; Trimmer, J. T.; Katende, D.; Mubasira, M.; Nagirinya, M.; Nsereko, F.; Banadda, N.; Cusick, R. D.; Guest, J. S. Advancing Sustainable Sanitation and Agriculture through Investments in Human-Derived Nutrient Systems. Environ. Sci. Technol. 2020, 54 (15), 9217-9227. https://doi.org/10.1021/acs.est.0c03764.

(33) Ecoinvent 3.2 Database. Swiss Centre for Life Cycle Inventories 2016. 
(34) Bare, J. TRACI 2.0: The Tool for the Reduction and Assessment of Chemical and Other Environmental Impacts 2.0. Clean Technol. Environ. Policy 2011, 13 (5), 687-696. https://doi.org/10.1007/s10098-010-0338-9.

(35) Hutton, G.; Varughese, M. The Costs of Meeting the 2030 Sustainable Development Goal Targets on Drinking Water, Sanitation, and Hygiene; World Bank: Washington, D.C., 2016.

(36) McConville, J. R.; Kvarnström, E.; Maiteki, J. M.; Niwagaba, C. B. Infrastructure Investments and Operating Costs for Fecal Sludge and Sewage Treatment Systems in Kampala, Uganda. Urban Water J. 2019, 16 (8), 584-593.

https://doi.org/10.1080/1573062X.2019.1700290.

(37) Jacks, G.; Sefe, F.; Carling, M.; Hammar, M.; Letsamao, P. Tentative Nitrogen Budget for Pit Latrines - Eastern Botswana. Environ. Geol. 1999, 38 (3), 199-203.

https://doi.org/10.1007/s002540050415.

(38) Lagerstedt, E.; Jacks, G.; Sefe, F. Nitrate in Groundwater and N Circulation in Eastern Botswana. Environ. Geol. 1994, 23 (1), 60-64. https://doi.org/10.1007/BF00773140.

(39) Phillips, I.; Burton, E. Nutrient Leaching in Undisturbed Cores of an Acidic Sandy Podosol Following Simultaneous Potassium Chloride and Di-Ammonium Phosphate Application. Nutr. Cycl. Agroecosystems 2005, 73 (1), 1-14. https://doi.org/10.1007/s10705-0056080-8.

(40) Chowdhry, S.; Kone, D. Business Analysis of Fecal Sludge Management: Emptying and Transportation Services in Africa and Asia (Draft Final Report); Bill \& Melinda Gates Foundation, 2012.

(41) IPCC. 2019 Refinement to the 2006 IPCC Guidelines for National Greenhouse Gas Inventories, Volume 5: Waste; National Greenhouse Gas inventories Programme, Eggleston H.S., Buendia L., Miwa K., Ngara T. and Tanabe K. (eds): Japan, 2019.

(42) Murungi, C.; van Dijk, M. P. Emptying, Transportation and Disposal of Feacal Sludge in Informal Settlements of Kampala Uganda: The Economics of Sanitation. Habitat Int. 2014, 42, 69-75. https://doi.org/10.1016/j.habitatint.2013.10.011.

(43) Isunju, J. B.; Etajak, S.; Mwalwega, B.; Kimwaga, R.; Atekyereza, P.; Bazeyo, W.; Ssempebwa, J. C. Financing of Sanitation Services in the Slums of Kampala and Dar Es Salaam. Health (N. Y.) 2013, 5 (4), 783-791. https://doi.org/10.4236/health.2013.54104.

(44) IPCC. 2006 IPCC Guidelines for National Greenhouse Gas Inventories; Prepared by the National Greenhouse Gas Inventories Programme, Eggleston H.S., Buendia L., Miwa K., Ngara T. and Tanabe K. (eds.): IGES, Japan, 2006.

(45) IPCC. 2019 Refinement to the 2006 IPCC Guidelines for National Greenhouse Gas Inventories, Volume 4: Agriculture, Forestry and Other Land Use; National Greenhouse Gas inventories Programme, Eggleston H.S., Buendia L., Miwa K., Ngara T. and Tanabe K. (eds): Japan, 2019.

(46) Mihelcic, J. R.; Fry, L. M.; Myre, E. A.; Phillips, L. D.; Barkdoll, B. D. Field Guide to Environmental Engineering for Development Workers: Water, Sanitation, and Indoor Air, American Society of Civil Engineers: Reston, Virginia, 2009.

(47) EIA. International energy statistics https://www.eia.gov/beta/international/ (accessed Dec 8, 2018).

(48) Udert, K. M.; Larsen, T. A.; Gujer, W. Fate of Major Compounds in Source-Separated Urine. Water Sci. Technol. 2006, 54 (11-12), 413-420.

https://doi.org/10.2166/wst.2006.921.

(49) National Fertilizer Prices https://africafertilizer.org/national/ (accessed Mar 26, 2019).

(50) Tilley, E.; Ulrich, L.; Luthi, C.; Reymond, P.; Zurbrugg, C. Compendium of Sanitation Systems and Technologies, 2nd revised edition.; Swiss Federal Institute of Aquatic Science and Technology (Eawag): Dübendorf, Switzerland, 2014. 
(51) Vögeli, Y.; Lohri, C. R.; Gallardo, A.; Diener, S.; Christian, S. Anaerobic Digestion of Biowaste in Developing Countries: Practical Information and Case Studies. Swiss Federal Institute of Aquatic Science and Technology (Eawag), Dübendorf, Switzerland 2014.

(52) IGU. Natural Gas Conversion Guide. International Gas Union 2012.

(53) Balakrishnan, K.; Sambandam, S.; Ramaswamy, P.; Mehta, S.; Smith, K. R. Exposure Assessment for Respirable Particulates Associated with Household Fuel Use in Rural Districts of Andhra Pradesh, India. J. Expo. Sci. Environ. Epidemiol. 2004, 14 (S1), S14S25. https://doi.org/10.1038/sj.jea.7500354.

(54) GIZ. Multiple-Household Fuel Use - a Balanced Choice between Firewood, Charcoal, and LPG; Deutsche Gesellschaft fur Internationale Zusammenarbeit (GIZ) GmBH: Germany, 2014.

(55) EPA. Emission Factors for Greenhouse Gas Inventories. US Environ. Prot. Agency 2014, 5.

(56) Niwagaba, C.; Kulabako, R. N.; Mugala, P.; Jönsson, H. Comparing Microbial Die-off in Separately Collected Faeces with Ash and Sawdust Additives. Waste Manag. 2009, 29 (7), 2214-2219. https://doi.org/10.1016/j.wasman.2009.02.010.

(57) Udert, K. M.; Larsen, T. A.; Gujer, W. Estimating the Precipitation Potential in UrineCollecting Systems. Water Res. 2003, 37 (11), 2667-2677.

https://doi.org/10.1016/S0043-1354(03)00071-X.

(58) Udert, K. M.; Larsen, T. A.; Gujer, W. Biologically Induced Precipitation in UrineCollecting Systems. Water Supply 2003, 3 (3), 71-78.

https://doi.org/10.2166/ws.2003.0010.

(59) Udert, K. M.; Larsen, T. A.; Biebow, M.; Gujer, W. Urea Hydrolysis and Precipitation Dynamics in a Urine-Collecting System. Water Res. 2003, 37 (11), 2571-2582. https://doi.org/10.1016/S0043-1354(03)00065-4.

(60) Ronteltap, M.; Maurer, M.; Gujer, W. Struvite Precipitation Thermodynamics in SourceSeparated Urine. Water Res. 2007, 41 (5), 977-984. https://doi.org/10.1016/j.watres.2006.11.046.

(61) Wohlsager, S.; Clemens, J.; Nguyet, P. T.; Rechenburg, A.; Arnold, U. Urine - A Valuable Fertilizer with Low Risk after Storage in the Tropics. Water Environ. Res. 2010, 82 (9), 840-847. https://doi.org/10.2175/106143010X12609736967125.

(62) Central Intelligence Agency. Central Bank Discount Rate https://www.cia.gov/library/publications/the-world-factbook/fields/230.html (accessed Jul 22, 2020).

(63) Kulabako, R. N.; Nalubega, M.; Wozei, E.; Thunvik, R. Environmental Health Practices, Constraints and Possible Interventions in Peri-Urban Settlements in Developing Countries - a Review of Kampala, Uganda. Int. J. Environ. Health Res. 2010, 20 (4), 231-257. https://doi.org/10.1080/09603120903545745.

(64) Nansubuga, I.; Banadda, N.; Verstraete, W.; Rabaey, K. A Review of Sustainable Sanitation Systems in Africa. Rev. Environ. Sci. Biotechnol. 2016, 15 (3), 465-478. https://doi.org/10.1007/s11157-016-9400-3.

(65) Peal, A.; Evans, B.; Ahilan, S.; Ban, R.; Blackett, I.; Hawkins, P.; Schoebitz, L.; Scott, R.; Sleigh, A.; Strande, L.; Veses, O. Estimating Safely Managed Sanitation in Urban Areas; Lessons Learned From a Global Implementation of Excreta-Flow Diagrams. Front. Environ. Sci. 2020, 8. https://doi.org/10.3389/fenvs.2020.00001.

(66) USDA. Food Composition Databases https://ndb.nal.usda.gov/ndb/search/list (accessed Aug 11, 2016).

(67) Turban, S.; Miller, E. R.; Ange, B.; Appel, L. J. Racial Differences in Urinary Potassium Excretion. J. Am. Soc. Nephrol. JASN 2008, 19 (7), 1396-1402.

https://doi.org/10.1681/ASN.2007101142. 
(68) Grau, F.; Choo, H.; Hu, J. W.; Jung, J. Engineering Behavior and Characteristics of Wood Ash and Sugarcane Bagasse Ash. Materials 2015, 8 (10), 6962-6977. https://doi.org/10.3390/ma8105353.

(69) Abdullahi, M. Characteristics of Wood Ash/OPC Concrete. Leonardo Electron. J. Pract. Technol. 2006, 8, 9-16.

(70) Demeyer, A.; Voundi Nkana, J. C.; Verloo, M. G. Characteristics of Wood Ash and Influence on Soil Properties and Nutrient Uptake: An Overview. Bioresour. Technol. 2001, 77 (3), 287-295. https://doi.org/10.1016/S0960-8524(00)00043-2.

(71) Serafimova, Ek.; Mladenov, M.; Mihailova, I.; Pelovski, Y. Study on the Characteristics of Waste Wood Ash. J. Univ. Chem. Technol. Metall. 2011, 46 (1), 31-34.

(72) Huang, H.; Campbell, A. G.; Folk, R.; Mahler, R. L. Wood Ash as a Soil Additive and Liming Agent for Wheat: Field Studies. Commun. Soil Sci. Plant Anal. 1992, 23 (1-2), 2533. https://doi.org/10.1080/00103629209368567.

(73) Etiegni, L.; Campbell, A. G.; Mahler, R. L. Evaluation of Wood Ash Disposal on Agricultural Land. I. Potential as a Soil Additive and Liming Agent. Commun. Soil Sci. Plant Anal. 1991, 22 (3-4), 243-256. https://doi.org/10.1080/00103629109368412.

(74) Misra, M. K.; Ragland, K. W.; Baker, A. J. Wood Ash Composition as a Function of Furnace Temperature. Biomass Bioenergy 1993, 4 (2), 103-116. https://doi.org/10.1016/0961-9534(93)90032-Y.

(75) Reid, M. C.; Guan, K.; Wagner, F.; Mauzerall, D. L. Global Methane Emissions from Pit Latrines. Environ. Sci. Technol. 2014, 48 (15), 8727-8734. https://doi.org/10.1021/es501549h.

(76) Shoener, B. D.; Bradley, I. M.; Cusick, R. D.; Guest, J. S. Energy Positive Domestic Wastewater Treatment: The Roles of Anaerobic and Phototrophic Technologies. Environ. Sci. Process. Impacts 2014, 16 (6), 1204-1222. https://doi.org/10.1039/C3EM00711A.

(77) Rittman, B. E.; McCarty, P. L. Environmental Biotechnology: Principles and Applications; McGraw-Hill: New York, 2001.

(78) National Slum Dwellers Federation of Uganda and ACTogether Uganda. Kampala Slum Settlement Profile: Kawempe; National Slum Dwellers Federation of Uganda and ACTogether Uganda: Kampala, Uganda, 2014.

(79) Prouty, C.; Zhang, Q. How Do People's Perceptions of Water Quality Influence the Life Cycle Environmental Impacts of Drinking Water in Uganda? Resour. Conserv. Recycl. 2016, 109, 24-33. https://doi.org/10.1016/j.resconrec.2016.01.019.

(80) Brant, R. Assessing Proportionality in the Proportional Odds Model for Ordinal Logistic Regression. Biometrics 1990, 46 (4), 1171-1178. https://doi.org/10.2307/2532457.

(81) Hardy, M. A.; Reynolds, J. Incorporating Categorical Information into Regression Models: The Utility of Dummy Variables. In Handbook of Data Analysis; Hardy, M. A., Bryman, A., Eds.; SAGE, 2009.

(82) Sharpe, D. Your Chi-Square Test Is Statistically Significant: Now What? Pract. Assess. Res. Eval. 2015, 20 (8), 1-10.

(83) Bauza, V.; Byrne, D. M.; Trimmer, J. T.; Lardizabal, A.; Atiim, P.; Asigbee, M. A. K.; Guest, J. S. Child Soil Ingestion in Rural Ghana - Frequency, Caregiver Perceptions, Relationship with Household Floor Material and Associations with Child Diarrhoea. Trop. Med. Int. Health 2018, 23 (5), 558-569. https://doi.org/10.1111/tmi.13050. 